\title{
Testing the ureilite projectile hypothesis for the El'gygytgyn impact: Determination of siderophile element abundances and Os isotope ratios in ICDP drill core samples and melt rocks
}

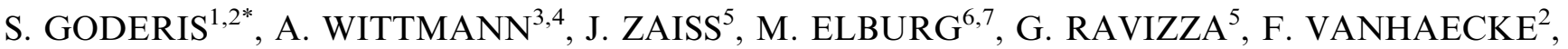 \\ A. DEUTSCH ${ }^{8}$, and P. CLAEYS ${ }^{1}$ \\ ${ }^{1}$ Department of Geology, Earth System Science, Vrije Universiteit Brussel, Pleinlaan 2, Brussels BE-1050, Belgium \\ ${ }^{2}$ Department of Analytical Chemistry, Ghent University, Krijgslaan 281-S12, Ghent BE-9000, Belgium \\ ${ }^{3}$ Department of Earth and Planetary Sciences, Washington University St. Louis, Campus Box 1169, 1 Brookings Dr., St. Louis, \\ Missouri 63130-4899, USA \\ ${ }^{4}$ Lunar and Planetary Institute, 3600 Bay Area Blvd., Houston, Texas 77058 USA \\ ${ }^{5}$ Department of Geology and Geophysics, University of Hawaii at Manoa, Honolulu, Hawai'i USA \\ ${ }^{6}$ Department of Geology \& Soil Sciences, Ghent University, Krijgslaan 281-S8, Ghent BE-9000, Belgium \\ ${ }^{7}$ School of Agricultural, Earth and Environmental Sciences, University of KwaZulu-Natal, Durban, South Africa \\ ${ }^{8}$ Institut für Planetologie, Westfälische Wilhelms-Universität Münster, Wilhelm-Klemm-Str. 10, Münster D-48149, Germany \\ *Corresponding author. E-mail: Steven.Goderis@vub.ac.be
}

(Received 15 February 2012; revision accepted 29 October 2012)

\begin{abstract}
The geochemical nature of the impactites from International Continental Scientific Drilling Project-El'gygytgyn lake drill core $1 \mathrm{C}$ is compared with that of impact melt rock fragments collected near the western rim of the structure and literature data. Concentrations of major and trace elements, with special focus on siderophile metals $\mathrm{Cr}, \mathrm{Co}, \mathrm{Ni}$, and the platinum group elements, and isotope ratios of osmium (Os), were determined to test the hypothesis of an ureilite impactor at El'gygytgyn. Least squares mixing calculations suggest that the upper volcanic succession of rhyolites, dacites, and andesites were the main contributors to the polymict impact breccias. Additions of $2-13.5 \mathrm{vol} \%$ of basaltic inclusions recovered from drill core intervals between 391.6 and 423.0 mblf can almost entirely account for the compositional differences observed for the bottom of a reworked fallout deposit at 318.9 mblf, a polymict impact breccia at 471.4 mblf, and three impact melt rock fragments. However, the measured Os isotope ratios and slightly elevated PGE content (up to $0.262 \mathrm{ng} \mathrm{g}^{-1} \mathrm{Ir}$ ) of certain impactite samples, for which the CI-normalized logarithmic PGE signature displays a relatively flat (i.e., chondritic) pattern, can only be explained by the incorporation of a small meteoritic contribution. This component is also required to explain the exceptionally high siderophile element contents and corresponding $\mathrm{Ni} / \mathrm{Cr}, \mathrm{Ni} / \mathrm{Co}$, and $\mathrm{Cr} / \mathrm{Co}$ ratios of impact glass spherules and spherule fragments that were recovered from the reworked fallout deposits and from terrace outcrops of the Enmyvaam River approximately $10 \mathrm{~km}$ southeast of the crater center. Mixing calculations support the presence of approximately $0.05 \mathrm{wt} \%$ and $0.50-18 \mathrm{wt} \%$ of ordinary chondrite (possibly typeLL) in several impactites and in the glassy spherules, respectively. The heterogeneous distribution of the meteoritic component provides clues for emplacement mechanisms of the various impactite units.
\end{abstract}




\section{INTRODUCTION}

\section{The El'gygytgyn Impact Crater}

El'gygytgyn is an $18 \mathrm{~km}$ diameter, $3.58 \pm 0.04 \mathrm{Ma}$ old, very well preserved impact crater centered at $67^{\circ} 30^{\prime} \mathrm{N}$ and $172^{\circ} 34^{\prime} \mathrm{E}$ on the NE Siberian Chukotka peninsula (Gurov et al. 1978; Layer 2000; Gurov and Koeberl 2004). An asymmetrically offset, $12 \mathrm{~km}$ diameter and up to $170 \mathrm{~m}$ deep lake, which is studied for its paleoclimatic record (e.g., Nowaczyk et al. 2002; Melles et al. 2005, 2011, 2012; Gebhardt et al. 2006), occupies the central depression. El'gygytgyn's central crater contains a $7-7.5 \mathrm{~km}$ diameter and $2 \mathrm{~km}$ wide central ring, instead of a central uplift. Seismic data document the stratigraphic succession in the central crater (Gebhardt et al. 2006) with a $170 \mathrm{~m}$ thick upper and a 190-250 $\mathrm{m}$ thick lower lacustrine sedimentary unit underlain by $100-400 \mathrm{~m}$ thick impact breccias lying on top of fractured bedrock.

A generalized preimpact upper target stratigraphy of 83.2-89.3 Ma old volcanic rocks (Belyi 1998; Layer 2000; Gurov et al. 2007) was established by Gurov and Gurova (1991) and comprises, from top to bottom, $250 \mathrm{~m}$ rhyolitic ignimbrites, $200 \mathrm{~m}$ of rhyolitic tuffs and lavas, $70 \mathrm{~m}$ of andesitic tuffs and lavas, and $100 \mathrm{~m}$ of rhyolitic and dacitic ash tuffs and welded tuffs. Paleocene basalts intruded this target assemblage (e.g., Glushkova and Smirnov 2005). Gurov et al. (1978, 1979, 2005), Gurov and Koeberl (2004), Feldman et al. (1981), Dabizha and Feldman (1982), and Kapustina et al. (1985) carried out petrographic work on shock metamorphosed rocks that occur on lake terraces and glacial deposits around the crater.

Geochemical studies of impactites from El'gygytgyn revealed enrichments in certain siderophile elements (e.g., Cr, Co, Ni, Ir), interpreted to reflect contamination with a meteoritic component. On the basis of resemblance of relative abundances of these siderophile elements in glassy melt bombs from El'gygytgyn to those of ureilites, Va'lter et al. (1982) characterized the impactor as a ureilite. Kapustina et al. (1985) studied volatilization trends of elements, including siderophiles in El'gygytgyn impactites. These authors confirmed the findings of Va'lter et al. (1982). Gurov and Koeberl (2004) presented additional trace element data for glassy impact melt from El'gygytgyn and concluded that an achondrite appears to be the most probable impactor type based on the relatively high $\mathrm{Cr}$ enrichment, but cautioned that "... no unambiguous conclusions regarding the presence and nature of a meteoritic component in the El'gygytgyn impactites can be made so far."
From February 2009 until May 2009, the Austrian Federal Ministry of Science and Research; the Federal Ministry of Education and Research, Germany; the International Continental Scientific Drilling Project (ICDP) Germany-German Science Foundation; the Russian Academy of Sciences; and the U.S. National Science Foundation funded the drilling of three holes ("Site 5011-1") on the frozen crater lake of El'gygytgyn. The deepest hole 1C, near the center of the lake penetrated $225.3 \mathrm{~m}$ of lacustrine sediments and $207.5 \mathrm{~m}$ of impactites, of which only $157.4 \mathrm{~m}(76 \%)$ were recovered, to a final depth of $517.3 \mathrm{~m}$ below the lake floor (mblf; Melles et al. 2011; Koeberl et al. 2013).

\section{Impactor Identification}

So far, distinct projectiles have been proposed (e.g., Tagle and Hecht 2006; Koeberl 2007; Goderis et al. 2012) for less than $20 \%$ of the 183 impact structures recognized on Earth today (Earth Impact Database 2012). During crater formation on a solid planetary surface, the impactites incorporate traces of meteoritic material (vapor, melt, or solid fragments) that induce a geochemical signature distinct from local or average crustal values. On Earth, in addition to atypical isotope ratios (e.g., ${ }^{187} \mathrm{Os} /{ }^{188} \mathrm{Os},{ }^{53} \mathrm{Cr} /{ }^{52} \mathrm{Cr}$, and ${ }^{54} \mathrm{Cr} /{ }^{52} \mathrm{Cr}$ ), elevated concentrations of specific siderophile elements (e.g., $\mathrm{Cr}, \mathrm{Co}, \mathrm{Ni}$, and the platinum group elements [PGEs: Ru, Rh, Pd, Os, Ir, Pt]) and inter-element ratios (e.g., $\mathrm{Rh} / \mathrm{Ir}, \mathrm{Pt} / \mathrm{Pd}$, etc.) can be used to constrain the extraterrestrial components of impactites. Because PGE concentrations in chondrites (Tagle and Berlin 2008) are generally two to four orders of magnitude higher than common terrestrial crustal or mantle abundances, these highly siderophile elements are ideally suited for the detection and characterization of minute amounts of extraterrestrial material admixed in impactites. However, this approach is of limited use for PGE-poor meteorites, including specific types of differentiated achondrites. In terrestrial impactites, bulk meteoritic contributions generally amount to less than $1 \mathrm{wt} \%$ (Koeberl 2007). Normally, projectile contributions in terrestrial impactites occur in impact melt rock (e.g., Palme et al. 1978, 1981; McDonald et al. 2001; McDonald 2002; Tagle and Claeys 2005). Nonetheless, other impactites can also contain enrichments in projectile components, as documented for the distal ejecta distributed worldwide at the CretaceousPaleogene (K/Pg) boundary (e.g., Alvarez et al. 1980; Smit and Hertogen 1980; Claeys et al. 2002). Due to its diluted concentration, meteoritic material is often heterogeneously distributed in impact melt rocks compared with the more uniform composition in major (and some trace) elements (Grieve et al. 1977). For 
El'gygytgyn, Va'lter et al. (1982) suggest that impact melt bombs have the highest probability to contain a meteoritic component, based on a comparison with melt bombs from the Zhamanshin impact crater. In the latter, drop-shaped irghizites carry pronounced traces of contamination by meteoritic matter, whereas massive impactites (zhamanshinites) do not (e.g., Palme et al. 1981). Previous studies of the siderophile element content in impact melt rocks and glasses of the El'gygytgyn impact structure have detected only minor enrichments in $\mathrm{Cr}, \mathrm{Co}, \mathrm{Ni}$, and $\mathrm{Ir}$ (on the order of approximately $100 \mathrm{pg} \mathrm{g}^{-1}$ Ir; Va'lter et al. 1982; Kapustina et al. 1985; Gurov and Koeberl 2004).

We aimed to geochemically characterize the impactite section in drill core samples of ICDPEl'gygytgyn hole $1 \mathrm{C}$, including comparison with impact melt rock fragments that were collected on the surface of the crater. One goal is the reconstruction of the proportion of target rock components that contributed to the polymict impact breccias. The second goal is the identification of a meteoritic component using siderophile element abundances and Os isotope ratios in the available impactite samples. Finally, we want to characterize the nature and distribution of projectile components throughout the impactite drill core section.

\section{SAMPLES}

Seventeen samples were selected from the impactite section of the El'gygytgyn ICDP 1C drill core for geochemical characterization (Table 1). Based on macroscopic (Fig. 1a-f) and thin section examination, the drill core was stratigraphically subdivided (see Wittmann et al. 2012). Its upper part consists of lacustrine deposits that are followed by a reworked fallout deposit from 315.4 to 319.4 mblf. This unit is underlain by suevite (polymict breccia with rare impact melt particles) from 319.4 to 329.1 mblf with core loss masking the boundary toward the top of the upper polymict impact breccia (330.8-419.3 mblf). The lower portion of the drill core consists of monomictly brecciated ignimbrites that contain mafic inclusions between 420.3 to $420.9 \mathrm{mblf}$ and 422.4 to $422.7 \mathrm{mblf}$, and a section of lower polymict breccia between 471.3 and 472.1 mblf. Major units below the lacustrine deposit were sampled for geochemical characterization (Fig. 2), with a main focus on the reworked fallout deposit, suevite, and polymict impact breccia. In the reworked fallout deposit, glass spherules (Fig. 3), diaplectic quartz glass with coesite, quartz with planar deformation features (PDF), and millimeter-sized impact melt particles occur. The reworked fallout deposit appears to be composed of 7-11 fining-upward sequences of breccias, gravels, and sands topped by lacustrine
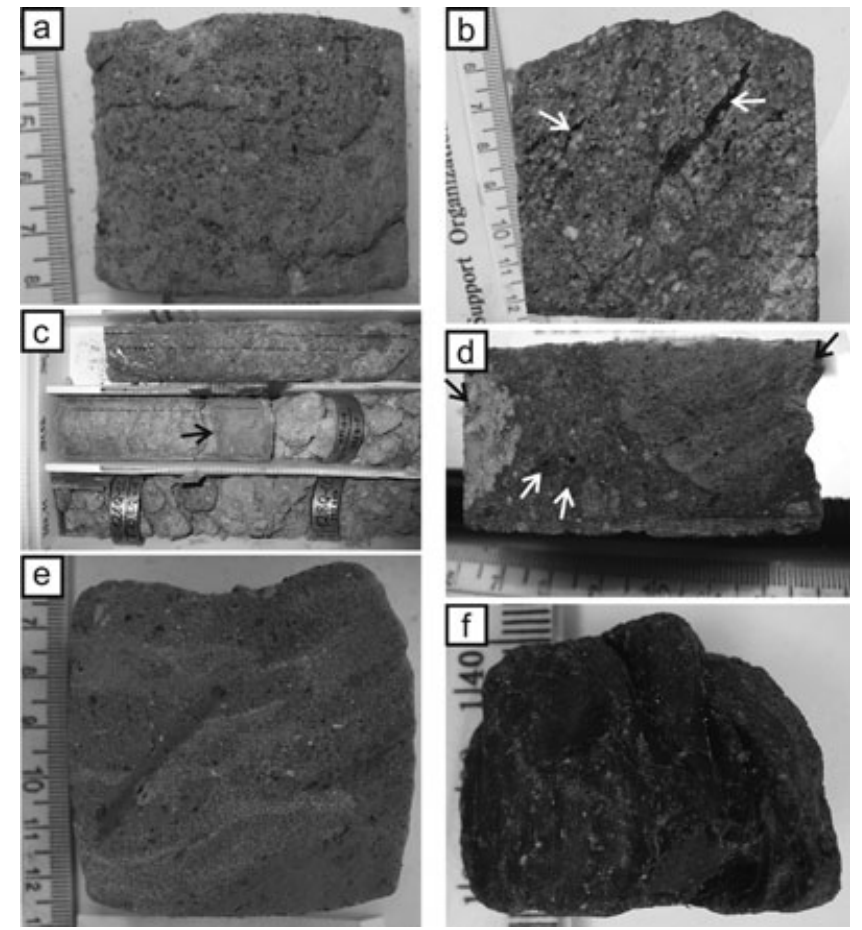

Fig. 1. a) Lower polymict impact breccia sample 471.4 mblf; b) upper ignimbrite sample 435.4 mblf, note dark brown melt streaks (arrows) elongated in a uniform direction; c) green, mafic inclusion sample 391.6 mblf (arrow) in brecciated ignimbrite of core box 126, core diameter is approximately $6.6 \mathrm{~cm}$; d) suevite sample 326.1 mblf with two tuff clasts (black arrows) at left and right end of sample, and two possible mantled clasts (white arrows); e) reworked fallout deposit sample 318.9 mblf, note medium sand matrix that embeds slivers of fine-grained breccia; f) glassy impact melt clast TM17; ruler scales in all sample photographs are in $\mathrm{cm}$.

background sedimentation. Based on spherule-bearing samples $318.9,317.6$, and 316.7 mblf, abundances vary from 0.8 to 1.4 spherules $\mathrm{cm}^{-2}$ (Wittmann et al. 2012). Assuming a mean spherule diameter of $0.3 \mathrm{~mm}$, extrapolation of the lower spherule abundance over the thickness of the reworked fallout deposit results in a spherule layer that was originally approximately $10 \mathrm{~mm}$ thick (Wittmann et al. 2012). In the underlying suevite, diagnostic shock metamorphic features are rare and mainly present in form of up to $0.4 \mathrm{~cm}$ long isotropic, glassy impact melt particles. The underlying polymict breccia and ignimbrite are mostly devoid of diagnostic shock features (Raschke et al. 2013; Wittmann et al. 2012). Consequently, the reworked fallout deposit and suevite units are the units that most likely contain a meteoritic component. It was either directly incorporated during the main phase of crater formation or added as fallback material toward the end of the cratering process.

In addition, three glassy impact melt rock fragments (12-28 $\mathrm{g}$ in mass; $2-5 \mathrm{~cm}$ long) collected 
Table 1. Petrographic descriptions of the El'gygytgyn ICDP drill core samples and impact melt rocks analyzed in this study.

\begin{tabular}{|c|c|c|c|c|}
\hline $\begin{array}{l}\text { Sample } \\
\text { depth } \\
\text { (mblf) }\end{array}$ & Lithology & Microscopic description & $\begin{array}{l}\text { Sample } \\
\text { mass }(\mathrm{g})\end{array}$ & $\begin{array}{l}\text { Analytical } \\
\text { methods }\end{array}$ \\
\hline 316.7 & $\begin{array}{l}\text { Reworked } \\
\text { fallout } \\
\text { deposit }\end{array}$ & $\begin{array}{l}\text { Layered and size-sorted, matrix-supported polymict } \\
\text { microbreccia with few shock metamorphic features } \\
\text { in quartz and feldspar and few glassy impact melt } \\
\text { shards, and three spherules, one of which is hollow. } \\
\text { One round hole may be a trace of where a spherule } \\
\text { was plucked during preparation of the thin section. }\end{array}$ & 95.14 & $\begin{array}{l}\text { ICP-OES, } \\
\text { NiS-ICP-MS, } \\
\text { NiS-ID-ICP-MS }\end{array}$ \\
\hline 317.6 & $\begin{array}{l}\text { Reworked } \\
\text { fallout } \\
\text { deposit }\end{array}$ & $\begin{array}{l}\text { Unsorted polymict breccia with up to } 7 \mathrm{~mm} \text { long felsic volcanic } \\
\text { clasts. It contains } 3 \text { grains of diaplectic quartz glass with coesite } \\
\text { and abundant }<<1 \mathrm{~mm} \text {-size impact melt shards, and a few quartz } \\
\text { clasts with PDF. Four glass spherules occur, two of which contain } \\
\text { Ni-rich spinel, and one of which is hollow. } \\
\text { Also, one spherule-shaped hole is present, } \\
\text { where a spherule was plucked. }\end{array}$ & 59.72 & $\begin{array}{l}\text { ICP-OES, } \\
\text { NiS-ICP-MS, } \\
\text { NiS-ID-ICP-MS }\end{array}$ \\
\hline 318.9 & $\begin{array}{l}\text { Reworked } \\
\text { fallout } \\
\text { deposit }\end{array}$ & $\begin{array}{l}\text { Up to } 1 \mathrm{~cm} \text { long, polymict microbreccia fragments are } \\
\text { embedded in a sand matrix. Exclusively in the breccia } \\
\text { domains, one } 0.15 \mathrm{~mm} \text { diameter spherule with Ni-rich } \\
\text { spinel grains and } 8 \text { round to oval, } 0.1 \text { to } 0.23 \mathrm{~mm} \\
\text { diameter holes where spherules were plucked during } \\
\text { preparation of the thin section occur. No shock } \\
\text { metamorphic features or impact melt particles are present. }\end{array}$ & 54.67 & $\begin{array}{l}\text { ICP-OES, } \\
\text { NiS-ICP-MS, } \\
\text { NiS-ID-ICP-MS }\end{array}$ \\
\hline 323.9 & Suevite & $\begin{array}{l}\text { The sample is a polymict breccia with variegated clasts } \\
\text { of felsic and mafic volcanics, including gray tuff clasts. } \\
\text { All clasts appear more strongly affected by hydrothermal } \\
\text { alteration than in the other samples of this sub-unit. } \\
\text { Few features that may indicate a low }(<10 \mathrm{GPa}) \text { shock } \\
\text { metamorphic overprint occur and the few impact melt } \\
\text { particles have a yellowish color, suggesting alteration. }\end{array}$ & 47.86 & $\begin{array}{l}\text { ICP-OES, } \\
\text { NiS-ICP-MS }\end{array}$ \\
\hline 325.7 & Suevite & $\begin{array}{l}\text { Just one quartz grain with possible planar fractures occurs, but this } \\
\text { sample contains the largest vesicular, glassy impact melt particle in } \\
\text { the suevite unit with a length of } 3.6 \mathrm{~mm} \text { along with a few more } \\
\text { shard-shaped impact melt particles. Felsic volcanics, mainly tuff and } \\
\text { basalt, constitute the bulk of clast material. }\end{array}$ & 26.87 & $\begin{array}{l}\text { ICP-OES, } \\
\text { NiS-ICP-MS }\end{array}$ \\
\hline 326.1 & Suevite & $\begin{array}{l}\text { Thin section captures two }>1 \mathrm{~cm} \text { size tuff clasts that sandwich a } \\
\text { domain of polymict impact breccia that contains } \\
\text { felsic and mafic volcanics and several isotropic, vesicular impact melt } \\
\text { particles, typically } 0.1 \mathrm{~mm} \text { in size. } \\
\text { A } 1 \mathrm{~mm} \text { shocked quartz clast occurs with } 2 \text { sets } \\
\text { of intersecting, undecorated PDF. }\end{array}$ & 46.38 & $\begin{array}{l}\text { ICP-OES, } \\
\text { NiS-ICP-MS }\end{array}$ \\
\hline 327.8 & Suevite & Light gray, vesicular (tuff) clast that has a very low density & 14.24 & $\begin{array}{l}\text { ICP-OES, } \\
\text { NiS-ICP-MS }\end{array}$ \\
\hline 328.1 & Suevite & $\begin{array}{l}\text { Layered polymict breccia with an upper part that is } \\
\text { clast-supported and a lower, porous domain that is } \\
\text { matrix-supported. The clast supported portion contains } \\
\text { abundant basalt fragments, and one rounded, } \\
0.2 \mathrm{~mm} \text { particle is isotropic glass with a small gas bubble. } \\
\text { The matrix supported portion contains } \\
\text { mainly felsic volcanic clasts, including tuff. A partly isotropic, glassy } \\
\text { particle with elongated vesicles in the matrix supported portion is } \\
\text { petrographically similar to the impact melt particles in the samples above. } \\
\text { Apart from the two glassy possible impact melt particles, } \\
\text { no shock metamorphic features were found in this sample thin section. }\end{array}$ & 76.02 & $\begin{array}{l}\text { ICP-OES, } \\
\text { NiS-ICP-MS }\end{array}$ \\
\hline
\end{tabular}


Table 1. Continued. Petrographic descriptions of the El'gygytgyn ICDP drill core samples and impact melt rocks analyzed in this study.

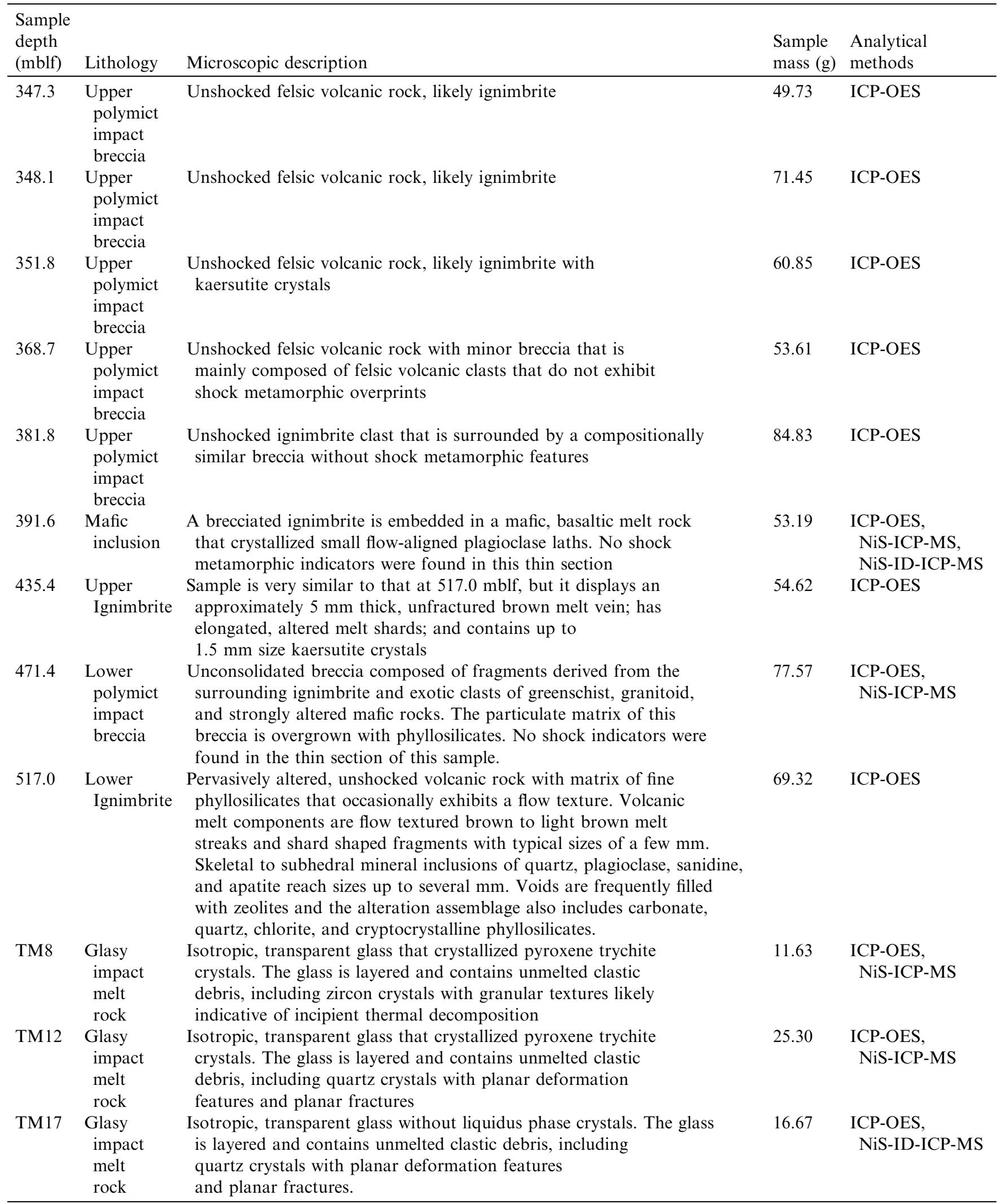




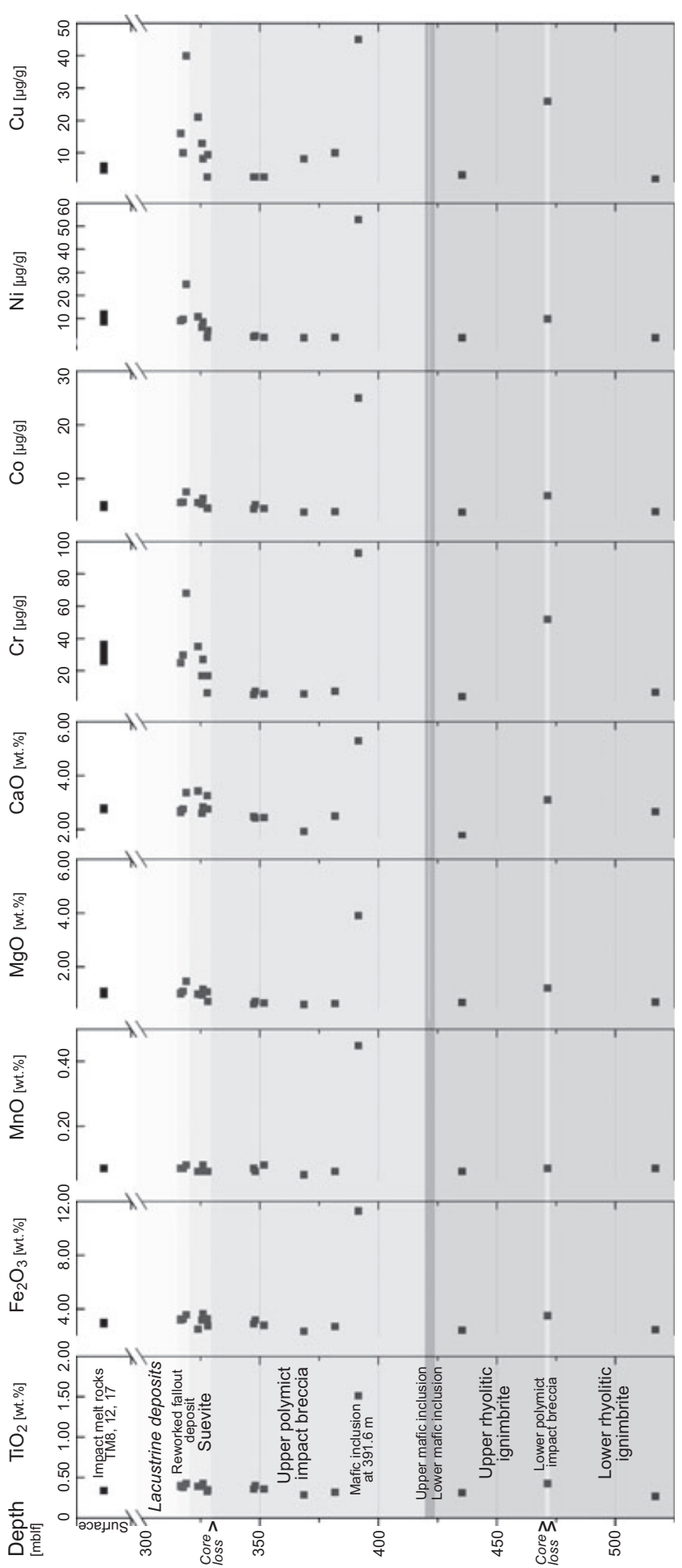

Fig. 2. Profile plot of $\mathrm{TiO}_{2}, \mathrm{Fe}_{2} \mathrm{O}_{3}, \mathrm{MnO}, \mathrm{MgO}, \mathrm{CaO}, \mathrm{Cr}$, $\mathrm{Co}, \mathrm{Ni}$, and $\mathrm{Cu}$ concentrations versus drill core depth (mblf). The various subunits characterized by Wittmann et al. (2012) are indicated by different shades of gray: lacustrine deposits, reworked fallout deposit, suevite, polymict impact breccia, and rhyolitic ignimbrite. Impact melt rocks, recovered from the surface of the crater, are presented for comparison.
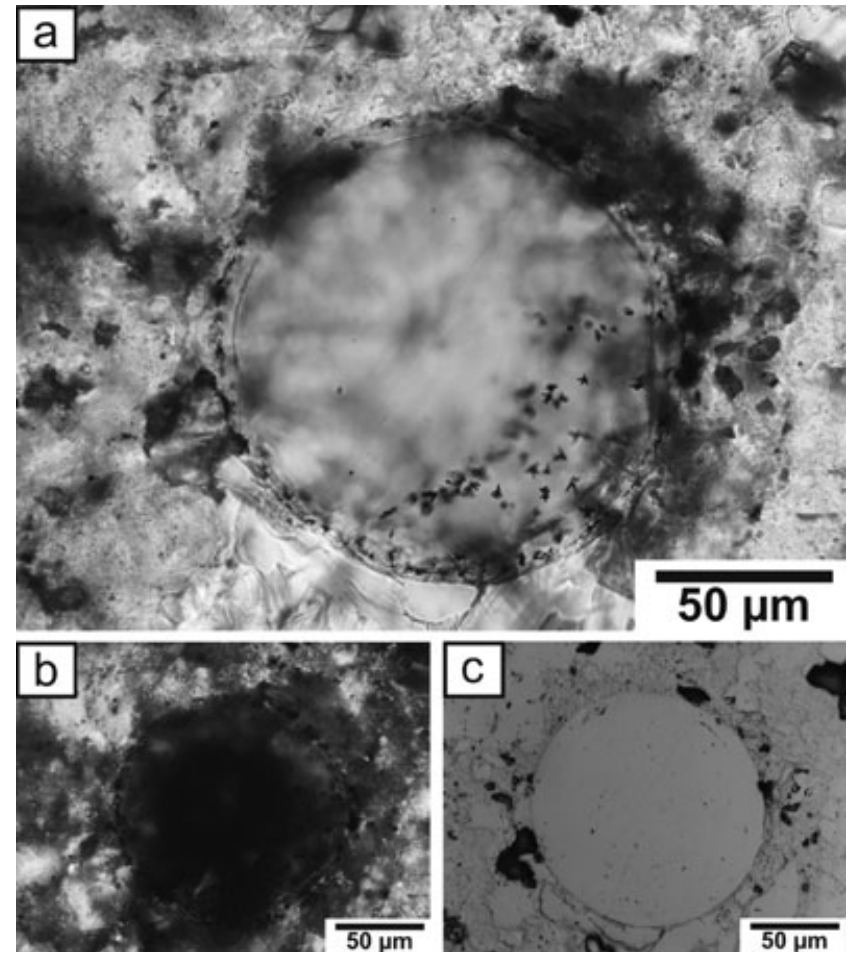

Fig. 3. Micrographs of El'gygtgyn impact spherule Sph8 in a thin section of the reworked fallout deposit at 317.6 mblf. a) Linear polarized light, black crystal inclusions are likely Nirich spinels; b) cross-polarized light; c) reflected light. For more details on the spherules recovered from the ICDP drill core and from a terrace deposit of the Enmyvaam River approximately $10 \mathrm{~km}$ southeast of the crater center, see Wittmann et al. (2012).

near the western rim of the impact crater were analyzed to complement the study of impact breccia samples from the continuous section of the ICDP drill hole. A short petrographic description of these impact melt rocks is also given in Table 1, with a picture of glassy impact melt clast TM17 in Fig. 1f. More details on these lithologies can be found in Wittmann et al. (2012).

\section{METHODOLOGY}

\section{Sample Preparation}

All samples were broken into smaller pieces with an agate mortar and pestle, ground to powder with a corundum ball mill, and thoroughly homogenized. The ground drill core sample masses ranged from 14 to $95 \mathrm{~g}$, while the impact melt rock fragments varied in mass from 12 to $25 \mathrm{~g}$ (Table 1). These powders were used in all subsequent analyses. Major and trace element abundances were determined using inductively coupled plasma-optical emission spectroscopy 
(ICP-OES) at Ghent University (Tables 2 and 3). Based on these results, 10 samples were selected for determination of their PGE contents (Table 4). Because the measured PGE concentrations were only slightly elevated compared with average continental crustal and local target lithology values, five samples were also characterized for their osmium isotopic composition $\left({ }^{187} \mathrm{Os} /{ }^{188} \mathrm{Os}\right.$ ) at the University of Hawaii (Table 5). This technique is generally considered the most sensitive method for the detection of minute contributions of projectile in terrestrial lithologies, provided no significant ultramafic component occurs in the target (e.g., Koeberl 2007).

Powder aliquots of $3-8 \mathrm{~g}$ were dried at $110^{\circ} \mathrm{C}$, and loss on ignition (LOI) was determined by heating at $950{ }^{\circ} \mathrm{C}$ for $2 \mathrm{~h}$. After LOI determination, approximately $150 \mathrm{mg}$ of sample powder was homogenized and fused with $0.6 \mathrm{~g}$ of $34: 66$ lithium meta-/tetraborate flux $\left(\mathrm{LiBO}_{2} / \mathrm{Li}_{2} \mathrm{~B}_{4} 0_{7}\right.$, Breitländer $)$ in high purity graphite crucibles at $1050{ }^{\circ} \mathrm{C}$. The resulting glass was dissolved in a $2 \mathrm{wt} \% \mathrm{HNO}_{3}$ solution and analyzed with a Spectro Arcos ICP-OES instrument for $\mathrm{Na}, \mathrm{Mg}, \mathrm{Al}, \mathrm{Si}, \mathrm{P}, \mathrm{K}, \mathrm{Ca}, \mathrm{Ti}, \mathrm{Mn}$, and $\mathrm{Fe}$ and selected trace elements ( $\mathrm{Sc}, \mathrm{V}, \mathrm{Cr}, \mathrm{Co}, \mathrm{Ni}, \mathrm{Cu}, \mathrm{Zn}, \mathrm{Sr}, \mathrm{Y}, \mathrm{Zr}$, $\mathrm{Ba}, \mathrm{La}, \mathrm{Ce}, \mathrm{Nd}$, Dy, $\mathrm{Yb}$ ). Selected rock reference materials were dissolved and analyzed following the same procedure, and subsequently used to produce optimal calibration curves, in the range of the sample concentrations measured. Accuracy was monitored by the analysis of secondary international rock standards (United States Geological Survey basalt BCR-2 and Geological Survey of Japan basalt JB-2; Table 3; GeoRem 2012), different from the primary standards used for the calibration curve. Accuracy for trace element determination was additionally verified by comparison with concentrations measured for in-house standards, previously characterized by acid digestion and subsequent analysis via ICP-mass spectrometry (MS). Analysis of drill core samples 318.9, 347.3, and 471.4 mblf, impact melt rock samples TM8 and TM12, and BCR-2, was repeated (Tables 2 and 3). The bias between the experimental results and the corresponding "true values" is estimated to be better than $2 \%$ and $10 \%$ for major and trace elements above $10 \mu \mathrm{g} \mathrm{g}^{-1}$, respectively.

The concentrations of the PGEs and Au were determined via a nickel-sulfide (NiS) fire assay sample preparation technique combined with sector field ICP-MS (Thermo-Finnegan Element 2/XR: Ghent University), according to a procedure first described in Plessen and Erzinger (1998), applied in Tagle and Claeys (2005), and further optimized by Goderis et al. (2010). The analytical methodology is described in these studies in detail. The use of large sample masses and external calibration versus a calibration curve for multiple isotopes when possible $\left({ }^{99} \mathrm{Ru},{ }^{101} \mathrm{Ru},{ }^{102} \mathrm{Ru}\right.$, ${ }^{103} \mathrm{Rh},{ }^{105} \mathrm{Pd},{ }^{106} \mathrm{Pd},{ }^{108} \mathrm{Pd},{ }^{191} \mathrm{Ir},{ }^{193} \mathrm{Ir},{ }^{194} \mathrm{Pt},{ }^{195} \mathrm{Pt}$, ${ }^{196} \mathrm{Pt}$, and ${ }^{197} \mathrm{Au}$ ), ensures good analytical accuracy and reproducibility, relatively low limits of detection and quantification (Table 4), and simultaneous measurement of all PGEs (except for Os that volatilizes during the sample preparation procedure). Each solution of approximately $10 \mathrm{ml}$ that was obtained after NiS fire assay preconcentration (aliquot masses are given in Table 4) was characterized twice for its PGE contents via ICP-MS on separate measuring days. The resulting concentrations were averaged and the range of the two analyses was used to estimate the analytical uncertainties for each element according to a method described in Anderson (1987) and Doerffel (1990). The standard deviation of a number $(n)$ of related samples of similar composition is determined as the square root of the square sum of the range of duplicated analyses divided by $2 \mathrm{n}$. The results obtained for international reference materials, diabase TDB-1 with low PGE abundances and the altered peridotite WPR-1 with high PGE concentrations (Canadian Certified Reference Materials Project, CCRMP), are consistent with the certified standard data (Govindaraju 1994) and the recommended values of Meisel and Moser (2004) (Table 4). The latter authors propose to compare new PGE data not only with the original certified values, but also with their compiled literature values until the certified values are up to date. Additionally, the precision and accuracy of the method are regularly tested by analysis of a set of in-house laboratory working standards (large batches of homogenized impact melt rock, $\mathrm{K} / \mathrm{Pg}$ boundary clay, and meteorites). To determine the procedural limits of detection (instrumental detection limits are significantly lower), procedural PGE blanks were determined by substitution of real samples with $\mathrm{SiO}_{2}$ powder. Omission of such a PGE-depleted substitute would result in a destruction of the clay crucibles by the aggressive fire assay flux. In this work, limit of detection (LOD) and limit of quantification (LOQ) were calculated as three and ten times the standard deviation ( $3 \mathrm{~s}$ and $10 \mathrm{~s}$ ) on 10 reagent blanks, respectively. Experimental values below the LOD are reported as N.D. (not detected), while concentrations below the LOQ are indicated as < numeral value of the LOQ in Table 4.

For the El'gygytgyn samples processed at the University of Hawaii (317.6, 316.7, 391.6 mblf, and TM17; Table 5), Os was preconcentrated from the same bulk rock powders via a NiS fire assay. Each sample powder was accurately weighed (approximately $5 \mathrm{~g}$ ) and spiked with a tracer solution enriched in 


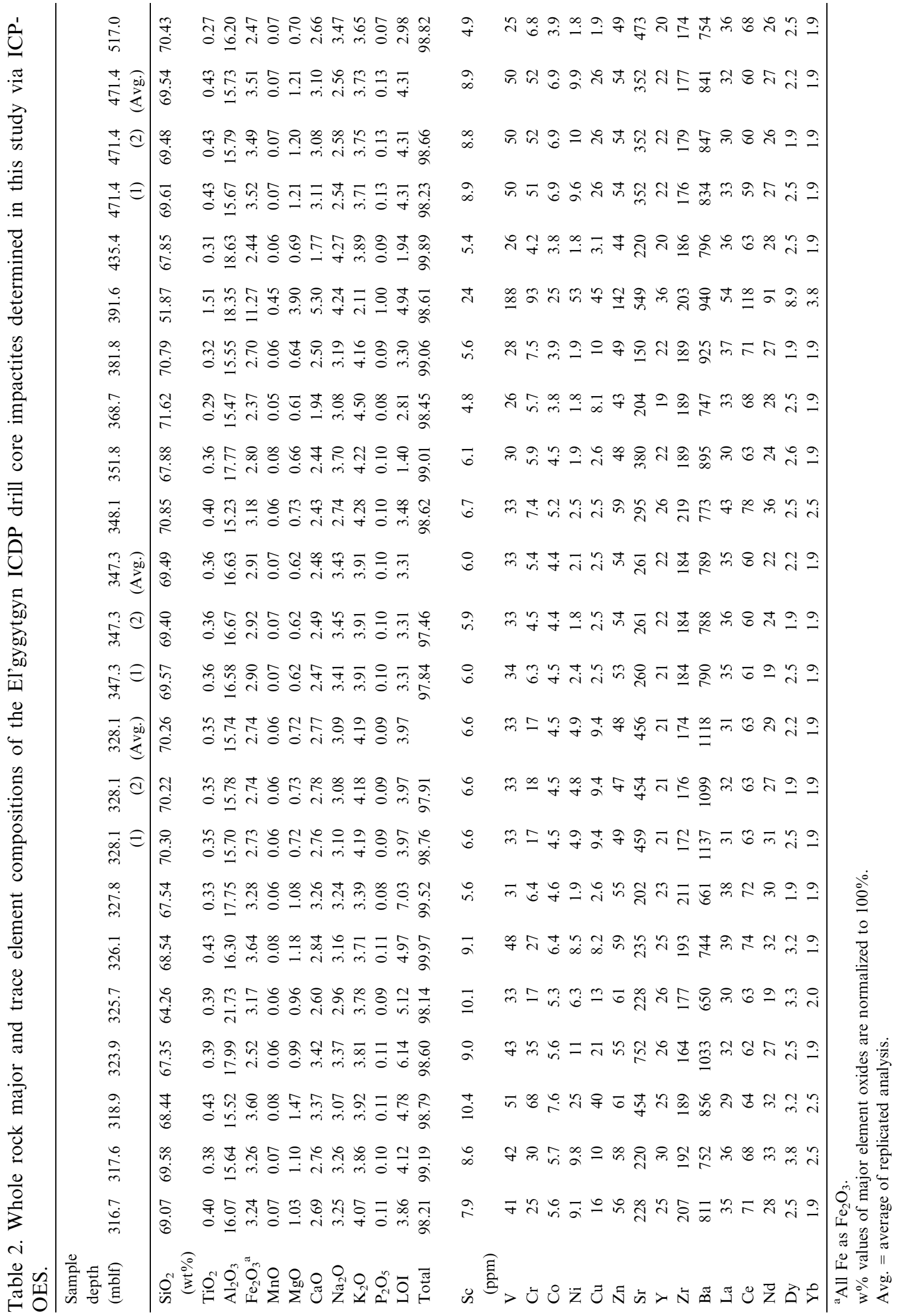


Table 3. Whole rock major and trace element compositions of the El'gygytgyn impact melt rocks determined in this study via ICP-OES, in comparison with international reference rock materials BCR-2 and JB-2.

\begin{tabular}{|c|c|c|c|c|c|c|c|c|c|c|c|c|c|}
\hline & TM8 & TM8 & TM8 & TM12 & TM17 & TM17 & TM17 & BCR-2 & BCR-2 & BCR-2 & BCR-2 (Lit.) & JB-2 & JB-2 (Lit.) \\
\hline & (1) & (2) & (Avg.) & & (1) & (2) & (Avg.) & (1) & (2) & (Avg.) & & & \\
\hline $\begin{array}{l}\mathrm{SiO}_{2} \\
(\mathrm{wt} \%)\end{array}$ & 68.97 & 68.84 & 68.90 & 69.33 & 69.33 & 69.19 & 69.26 & 54.26 & 54.24 & 54.25 & 54.10 & 53.06 & 53.25 \\
\hline $\mathrm{TiO}_{2}$ & 0.34 & 0.34 & 0.34 & 0.34 & 0.34 & 0.34 & 0.34 & 2.29 & 2.30 & 2.29 & 2.26 & 1.15 & 1.19 \\
\hline $\mathrm{Al}_{2} \mathrm{O}_{3}$ & 16.69 & 16.77 & 16.73 & 16.41 & 16.29 & 16.38 & 16.34 & 13.35 & 13.39 & 13.37 & 13.50 & 14.63 & 14.64 \\
\hline $\mathrm{Fe}_{2} \mathrm{O}_{3}{ }^{\mathrm{a}}$ & 2.93 & 2.95 & 2.94 & 3.00 & 2.97 & 2.98 & 2.97 & 13.89 & 13.92 & 13.91 & 13.80 & 14.22 & 14.25 \\
\hline $\mathrm{MnO}$ & 0.07 & 0.07 & 0.07 & 0.07 & 0.07 & 0.07 & 0.07 & 0.20 & 0.20 & 0.20 & 0.20 & 0.21 & 0.22 \\
\hline $\mathrm{MgO}$ & 1.09 & 1.10 & 1.10 & 1.04 & 0.98 & 0.99 & 0.98 & 3.54 & 3.56 & 3.55 & 3.59 & 4.53 & 4.62 \\
\hline $\mathrm{CaO}$ & 2.76 & 2.78 & 2.77 & 2.74 & 2.77 & 2.79 & 2.78 & 7.16 & 7.05 & 7.10 & 7.12 & 9.69 & 9.82 \\
\hline $\mathrm{Na}_{2} \mathrm{O}$ & 2.97 & 2.97 & 2.97 & 2.96 & 3.06 & 3.08 & 3.07 & 3.13 & 3.16 & 3.14 & 3.16 & 2.02 & 2.04 \\
\hline $\mathrm{K}_{2} \mathrm{O}$ & 4.11 & 4.11 & 4.11 & 4.03 & 4.10 & 4.11 & 4.11 & 1.83 & 1.84 & 1.83 & 1.79 & 0.40 & 0.42 \\
\hline $\mathrm{P}_{2} \mathrm{O}_{5}$ & 0.08 & 0.08 & 0.08 & 0.07 & 0.08 & 0.08 & 0.08 & 0.35 & 0.35 & 0.35 & 0.35 & 0.10 & 0.10 \\
\hline LOI & 0.48 & 0.48 & 0.48 & 0.09 & 0.12 & 0.12 & 0.12 & & & & & & \\
\hline Total & 98.21 & 97.91 & & 99.39 & 98.02 & 98.09 & & 99.01 & 99.05 & & 99.87 & 97.15 & 100.55 \\
\hline Sc (ppm) & 7.3 & 7.3 & 7.3 & 7.6 & 7.9 & 7.7 & 7.8 & 33 & 33 & 33 & 33 & 53 & 54 \\
\hline $\mathrm{V}$ & 36 & 36 & 36 & 38 & 36 & 37 & 37 & 409 & 410 & 409 & 416 & 555 & 575 \\
\hline $\mathrm{Cr}$ & 36.3 & 32.2 & 34 & 28 & 26 & 26 & 26 & 21 & 18 & 20 & 18 & 28 & 28 \\
\hline Co & 5.1 & 5.1 & 5.1 & 5.2 & 4.7 & 4.8 & 4.8 & 35 & 34 & 35 & 37 & 28 & 38 \\
\hline $\mathrm{Ni}$ & 12 & 12 & 12 & 11 & 10 & 8.5 & 9.1 & 12 & 14 & 13 & 18 & 14 & 17 \\
\hline $\mathrm{Cu}$ & 5.9 & 5.9 & 5.9 & 5.2 & 5.4 & 4.7 & 5.1 & 14 & 14 & 14 & 16 & 234 & 225 \\
\hline $\mathrm{Zn}$ & 34 & 34 & 34 & 28 & 33 & 33 & 33 & 139 & 138 & 139 & 127 & 113 & 108 \\
\hline $\mathrm{Sr}$ & 243 & 244 & 244 & 256 & 250 & 251 & 251 & 337 & 339 & 338 & 340 & 176 & 178 \\
\hline $\mathrm{Y}$ & 23 & 23 & 23 & 24 & 24 & 24 & 24 & 36 & 36 & 35.7 & 37.0 & 22 & 25 \\
\hline $\mathrm{Zr}$ & 220 & 221 & 221 & 195 & 187 & 188 & 188 & 185 & 188 & 186 & 184 & 47 & 51 \\
\hline $\mathrm{Ba}$ & 774 & 770 & 772 & 830 & 825 & 825 & 825 & 677 & 682 & 680 & 677 & 213 & 222 \\
\hline $\mathrm{La}$ & 32 & 34 & 33 & 36 & 35 & 35 & 35 & 27 & 28 & 27 & 25 & 1.9 & 2.4 \\
\hline $\mathrm{Ce}$ & 66 & 63 & 64 & 70 & 62 & 65 & 63 & 46 & 47 & 47 & 53 & 9.3 & 6.8 \\
\hline $\mathrm{Nd}$ & 12 & 19 & 15 & 29 & 20 & 19 & 20 & 31 & 23 & 27 & 28 & N.D. & 7 \\
\hline Dy & N.D. & 1.7 & 1.7 & 2.6 & 2.0 & 2.7 & 2.4 & 7.6 & 6.9 & 7.3 & 6.4 & 4.4 & 3.7 \\
\hline $\mathrm{Yb}$ & 1.7 & 1.7 & 1.7 & 2.0 & 2.0 & 2.0 & 2.0 & 4.4 & 4.4 & 4.4 & 3.5 & 4.4 & 2.6 \\
\hline
\end{tabular}

${ }^{\mathrm{a}} \mathrm{All} \mathrm{Fe}$ as $\mathrm{Fe}_{2} \mathrm{O}_{3}$.

$\mathrm{wt} \%$ values of major element oxides are normalized to $100 \%$.

Avg. $=$ average of replicated analysis.

${ }^{190}$ Os before fusion to determine concentrations by isotope dilution mass spectrometry. Osmium isotope ratios were measured using a single-collector sector field ICP-MS instrument (ThermoScientific Element 2), according to a procedure slightly modified from Hassler et al. (2000). In this method, $\mathrm{OsO}_{4}$ becomes volatile after oxidation and is transferred by an $\mathrm{Ar}$ gas stream directly into the plasma ("sparging"). An inhouse standard is analyzed after every five to six samples in each run to monitor the external reproducibility of the ${ }^{187} \mathrm{Os} /{ }^{188} \mathrm{Os}$ measurements. The average ${ }^{187} \mathrm{Os} /{ }^{188} \mathrm{Os}$ ratio of these measurements is $0.1082 \pm 0.0028 \quad(2 \quad$ S.D.; $n=20)$. Ten procedural fusion blanks were analyzed during the course of this study with an average of $0.30 \pm 0.20 \mathrm{pg}^{\mathrm{Os} \mathrm{g}^{-1}}$ sample and a ${ }^{187} \mathrm{Os} /{ }^{188} \mathrm{Os}$ ratio of approximately 0.87 . The total flux mass fused for each blank was $31.5 \mathrm{~g}$.
For every set of five to six Os isotope ratio measurements, Ar gas blanks were measured to monitor potential transfer of Os between analyses. Tabulated uncertainties in ${ }^{187} \mathrm{Os} /{ }^{188} \mathrm{Os}$ are derived from counting statistics (Table 5). Reported Os concentrations were calculated from measured ${ }^{190} \mathrm{Os} /{ }^{188} \mathrm{Os}$ ratios and all measured ratios yielded 2 sigma errors less than $2 \%$. However, given the very low Os concentrations in these reported impactites, the main source of uncertainty in the data is more likely to result from the procedural blank correction than from the counting statistics. Accuracy of the PGE concentrations is tested by repeated measurement of CCRMP reference material diabase TDB-1. Count rate for TM17 for ${ }^{187}$ Os was very low (approximately $200 \mathrm{cps}$ ), but as this is the only impact melt rock fragment measured, the ${ }^{187} \mathrm{Os} /{ }^{188} \mathrm{Os}$ is given nonetheless. 
Table 4. Concentrations of PGEs and Au in the impactites of El'gygytgyn, determined via NiS fire assay ICP-MS, in comparison with literature data.

\begin{tabular}{|c|c|c|c|c|c|c|c|}
\hline Sample depth (mblf) & $\operatorname{Ir}\left(\operatorname{ng~g}^{-1}\right)$ & $\mathrm{Ru}\left(\mathrm{ng} \mathrm{g}^{-1}\right)$ & Pt $\left(\right.$ ng g $\left.^{-1}\right)$ & $\mathrm{Rh}\left(\mathrm{ng} \mathrm{g}^{-1}\right)$ & $\mathrm{Pd}\left(\mathrm{ng} \mathrm{g}^{-1}\right)$ & $\mathrm{Au}\left(\mathrm{ng} \mathrm{g}^{-1}\right)$ & Aliquot mass \\
\hline TM12 & 0.142 & 0.164 & 0.358 & 0.081 & 0.158 & 0.587 & 20.6 \\
\hline TM8 & 0.203 & 0.231 & 0.483 & 0.092 & 0.319 & N.D. & 8.0 \\
\hline $318.9(1)$ & 0.262 & 0.360 & 0.745 & 0.120 & 0.283 & N.D. & 43.4 \\
\hline $318.9(2)$ & 0.094 & 0.263 & 0.424 & 0.061 & 0.332 & $<0.151$ & 4.2 \\
\hline 323.9 & $<0.041$ & $<0.082$ & 0.234 & $<0.035$ & N.D. & N.D. & 40.4 \\
\hline 325.7 & N.D. & $<0.082$ & 0.391 & 0.042 & 0.162 & N.D. & 20.0 \\
\hline 326.1 & N.D. & N.D. & 0.177 & $<0.035$ & N.D. & N.D. & 39.2 \\
\hline 327.8 & $<0.041$ & $<0.082$ & 0.182 & 0.045 & $<0.109$ & N.D. & 10.6 \\
\hline 328.1 & $<0.041$ & $<0.082$ & 0.289 & 0.044 & N.D. & N.D. & 46.0 \\
\hline $391.6(1)$ & $<0.041$ & 0.136 & 0.296 & 0.042 & 0.187 & N.D. & 21.3 \\
\hline $391.6(2)$ & $<0.041$ & $<0.082$ & 0.349 & 0.062 & 0.151 & N.D. & 10.0 \\
\hline $471.4(1)$ & 0.046 & $<0.082$ & 0.298 & 0.049 & $<0.109$ & N.D. & 46.8 \\
\hline $471.4(2)$ & 0.106 & 0.187 & 0.380 & 0.073 & 0.191 & N.D. & 8.3 \\
\hline EL 669-8 IMR ${ }^{\mathrm{a}}$ & $0.111( \pm 0.021)$ & n.a. & n.a. & n.a. & n.a. & 0.9 & n.d. \\
\hline EL $669-10 \mathrm{IMR}^{\mathrm{a}}$ & $0.073( \pm 0.017)$ & n.a. & n.a. & n.a. & n.a. & 0.3 & n.d. \\
\hline EL 689 glass bomb ${ }^{a}$ & $0.024( \pm 0.010)$ & n.a. & n.a. & n.a. & n.a. & 0.5 & n.d. \\
\hline TDB-1 $(n=4)$ & 0.103 & 0.301 & 5.334 & 0.523 & 23.321 & 5.937 & \\
\hline TDB-1 certified ${ }^{b}$ & 0.150 & 0.300 & $5.8( \pm 1.1)$ & 0.700 & $22.4( \pm 1.4)$ & $6.3( \pm 1.0)$ & \\
\hline TDB-1 recommended ${ }^{c}$ & 0.075 & 0.179 & 5.010 & 0.471 & 24.3 & & \\
\hline LOD & 0.012 & 0.024 & 0.016 & 0.010 & 0.033 & 0.045 & \\
\hline LOQ & 0.041 & 0.082 & 0.055 & 0.035 & 0.109 & 0.151 & \\
\hline Analytical uncertainty & 0.012 & 0.012 & 0.033 & 0.010 & 0.059 & 0.161 & \\
\hline
\end{tabular}

${ }^{\mathrm{a}}$ Gurov and Koeberl (2004).

${ }^{\mathrm{b}}$ TDB-1 certified values (Govindaraju 1994).

${ }^{\mathrm{c}}$ TDB-1 recommended values (Meisel and Moser 2004).

n.d. = not determined; n.a. = not applicable; $\mathrm{LOQ}=$ limit of quantification; LOD = limit of detection; analytical uncertainty: see text for detail.

Table 5. Data for the ${ }^{187} \mathrm{Os} /{ }^{188}$ Os isotope ratio and Os abundance in El'gygytgyn impactites.

\begin{tabular}{lcllc}
\hline $\begin{array}{l}\text { Sample depth } \\
\text { (mblf) }\end{array}$ & ${ }^{187}$ Os $/{ }^{188}$ Os & $\begin{array}{l}2 \sigma \\
\text { error }\end{array}$ & Os $\left(\mathrm{ng} \mathrm{g}^{-1}\right)$ & $\begin{array}{l}\% \text { blank } \\
\text { correction }^{\mathrm{d}}\end{array}$ \\
\hline TM17 & $\approx 0.2$ & & $0.003-0.005$ & $8 \%$ \\
$316.7^{\mathrm{a}}$ & 0.239 & 0.006 & 0.011 & $3 \%$ \\
$317.6^{\mathrm{a}}$ & 0.216 & 0.004 & 0.012 & $3 \%$ \\
$318.9^{\mathrm{a}}$ & 0.148 & 0.001 & 0.068 & $0 \%$ \\
$391.6^{\mathrm{b}}$ & 2.800 & 0.100 & 0.002 & $15 \%$ \\
\hline
\end{tabular}

${ }^{\mathrm{a}}$ Reworked fallout deposit sample.

${ }^{\mathrm{b}}$ Mafic inclusion.

${ }^{\mathrm{c}}$ Impact melt rock.

${ }^{\mathrm{d}}$ Indicates the magnitude of the blank correction for the Os isotope ratios.

\section{RESULTS}

\section{Composition of the Impactite Section in Drill Core ICDP-El'gygytgyn 1C and Implications for Target Rock Components in Impact Melt}

Major and trace element concentrations for the 20 bulk rock samples analyzed via ICP-OES in this study are presented in Tables 2 and 3 and Fig. 2. The results obtained for the drill core samples are in good agreement with published data (Gurov et al. 2005; Raschke et al. 2013) and indicate a moderately homogeneous, subalkaline, rhyodacitic character (with minor excursions to trachydacite; Fig. 4). In particular, the reworked fallout deposit is characterized by a homogeneous geochemistry, while the suevite and polymict impact breccia units show larger compositional variability. In the TAS diagram (Fig. 4), all but one whole rock drill core sample measured in this study plot within the range of whole rock compositions of the upper target rock sequence (Gurov et al. 2005). A mafic inclusion at 391.6 mblf (Fig. 1c) displays a basaltictrachyandesitic composition and stands out with higher abundances of $\mathrm{TiO}_{2}, \mathrm{Fe}_{2} \mathrm{O}_{3}, \mathrm{MnO}, \mathrm{MgO}, \mathrm{CaO}, \mathrm{Sc}, \mathrm{V}$, $\mathrm{Cr}, \mathrm{Co}, \mathrm{Ni}, \mathrm{Cu}, \mathrm{Zn}$, etc. (Table 2). This constituent is not described as a major component in the upper target rock sequence (Gurov et al. 2005), but is in agreement with preliminary data that reported basaltic target rock fragments in the drill core (Raschke et al. 2013). On a profile plot versus drill core depth, the concentrations for several major (e.g., $\mathrm{TiO}_{2}, \mathrm{Fe}_{2} \mathrm{O}_{3}, \mathrm{MnO}, \mathrm{MgO}, \mathrm{CaO}$ ) 


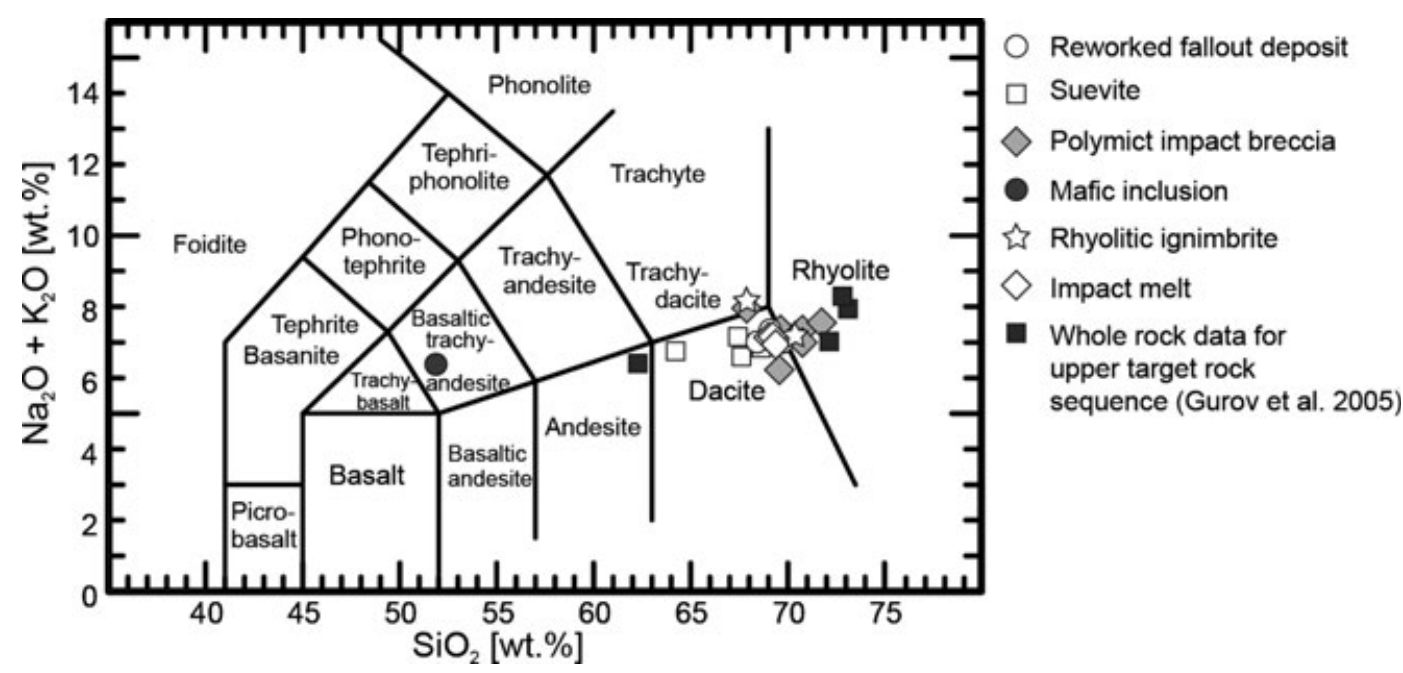

Fig. 4. Total alkali versus silica diagram adapted after Rollinson (1993). Next to the various subunits measured in the study, the whole rock data for the upper target sequence of Gurov et al. (2005) are given. Data are normalized to volatile-free compositions.

and trace (e.g., $\mathrm{Cr}, \mathrm{Co}, \mathrm{Ni}, \mathrm{Cu}$ ) elements show strong excursions in this mafic inclusion (Fig. 2). Secondary digressions away from the average drill core composition occur at the bottom of the reworked fallout deposit, the top of the suevite interval (318.9323.9 mblf), and the lower polymict breccia at 471.4 mblf in terms of $\mathrm{MgO}, \mathrm{CaO}, \mathrm{Cr}, \mathrm{Co}, \mathrm{Ni}$, and $\mathrm{Cu}$.

Using the rhyolitic ignimbrite encountered in the drill core at 435.4 and 517.0 mblf (upper and lower ignimbrite) as starting material, least squares mixing calculations were performed. The results suggest that an addition of $4.6-13.5 \mathrm{vol} \%$ of the mafic inclusions at 391.6 mblf (data from this study) and 391.7, 420.6, 420.9, 422.8, and $423.0 \mathrm{mblf}$ (data for (picro)basaltic inclusions from Raschke et al. 2013), could largely account for the secondary digressions observed for samples 471.4 and $318.9\left(\chi^{2} / v\right.$ of less than 3 ; with $\chi^{2}$ being the sum of least squares, and $v$, the number of major and minor elements plus $\mathrm{Cr}$, $\mathrm{Co}$, and $\mathrm{Ni}$, minus the number of components, i.e., rock compositions used for the mixing calculation; Korotev et al. 1995).

\section{Impact-Melt Rock Composition and Comparison with Published Data}

The impact melt rock fragments characterized in this study (TM8, 12, 17; Fig. 1f; Table 3) are very homogeneous in terms of major and trace element composition and almost identical in composition to the impact melt rocks (EL669-8 and 10) and glass bombs (EL689, 699, and 985) measured by Gurov and Koeberl (2004). Comparison with the 46 impact melt rocks and impact melt glasses characterized by Gurov et al. (2005) suggests that TM8, 12, and 17 are compositionally most similar to the average for the rhyolitic impact melt rocks from the $\mathrm{SW}, \mathrm{W}, \mathrm{NW}, \mathrm{N}, \mathrm{NE}$, and $\mathrm{E}$ parts of the crater. Less compositional similarity exists with the andesitic impact melt rocks from the southern part of the crater (Fig. 4). Similar to sample 471.4 mblf, TM8, 12 , and 17 can be tentatively modeled to represent mixtures of 2.0 to $6.0 \mathrm{vol} \%$ of the basaltic inclusions recovered from drill core intervals between 391.6 and $423.0 \mathrm{mblf}\left(\chi^{2} / v\right.$ of less than 3 for major and minor elements, plus $\mathrm{Cr}, \mathrm{Co}$, and $\mathrm{Ni}$ ) with the lower rhyolitic ignimbrite at 517.0 mblf as major hypothetical target $(>85 \mathrm{vol} \%)$ and minor contributions of the upper rhyolitic ignimbrite at 435.4 mblf.

\section{Moderately Siderophile Element Abundances and Implications for a Meteoritic Component}

Strong geochemical variability is observed for the siderophile trace element abundances. The highest siderophile trace element abundances of the 1C drill core bulk rock samples characterized in this study are measured for the mafic inclusion at 391.6 mblf $\left(\mathrm{Cr}=93 \mu \mathrm{g} \mathrm{g}^{-1}, \mathrm{Co}=25 \mu \mathrm{g} \mathrm{g}^{-1}, \mathrm{Ni}=53 \mu \mathrm{g} \mathrm{g}^{-1}\right)$, the bottom of the reworked fallout deposits at 318.9 mblf $\left(\mathrm{Cr}=68 \mu \mathrm{g} \mathrm{g}^{-1}, \mathrm{Co}=7.6 \mu \mathrm{g} \mathrm{g}^{-1}, \mathrm{Ni}=25 \mu \mathrm{g} \mathrm{g}^{-1}\right)$, and the polymict breccia at 471.4 mblf $\left(\mathrm{Cr}=52 \mu \mathrm{g} \mathrm{g}^{-1}\right.$, $\mathrm{Co}=6.9 \mu \mathrm{g} \mathrm{g}^{-1}, \quad \mathrm{Ni}=9.9 \mu \mathrm{g} \mathrm{g}^{-1}$; Table 2; Fig. 2). Higher concentrations of $\mathrm{Cr}$ (up to $945 \mu \mathrm{g} \mathrm{g}^{-1}$ ), Co (up to $52 \mu \mathrm{g} \mathrm{g}^{-1}$ ), and $\mathrm{Ni}$ (up to $278 \mu \mathrm{g} \mathrm{g}^{-1}$ ) are reported for basaltic inclusions between 420.6 and $423.0 \mathrm{mblf}$ by Raschke et al. (2013). Gurov et al. (2005) report up to $145 \mu \mathrm{g} \mathrm{g}^{-1} \mathrm{Cr}$, up to $7.9 \mu \mathrm{g} \mathrm{g}^{-1} \mathrm{Co}$, and up to 
Table 6. Comparison of the measured $\mathrm{Ni} / \mathrm{Cr}, \mathrm{Ni} / \mathrm{Co}$, and $\mathrm{Cr} / \mathrm{Co}$ ratios of the El'gygytgyn impactites and impact glass spherules to the upper continental crust and several types of meteorites.

\begin{tabular}{|c|c|c|c|c|c|}
\hline & $\mathrm{Ni} / \mathrm{Cr}$ & $\mathrm{Ni} / \mathrm{Co}$ & $\mathrm{Cr} / \mathrm{Co}$ & Avg. Ni (ppm) ${ }^{\mathrm{b}}$ & References \\
\hline $\mathrm{UCC}$ & $\sim 0.5$ & $1.6-2.6$ & $2.9-5.0$ & & $\begin{array}{l}\text { Wedepohl (1995), Taylor } \\
\text { and McLennan (1985) }\end{array}$ \\
\hline $\mathrm{LCC}$ & $\sim 0.43$ & $\sim 2.6$ & $\sim 6.0$ & & Wedepohl (1995) \\
\hline Regression analysis on impactites & $0.47 \pm 0.04$ & $2.43 \pm 0.20$ & $4.16 \pm 0.70$ & & This study \\
\hline Avg. reworked fallout deposit & 0.35 & 2.21 & 6.20 & & This study \\
\hline Avg. suevite & 0.30 & 1.16 & 3.84 & & This study \\
\hline Mafic inclusions & $0.19-0.95$ & $2.12-5.84$ & $3.15-21.86$ & & $\begin{array}{l}\text { This study, Raschke et al. } \\
\text { (2013) }\end{array}$ \\
\hline Impact glass spherules & $2.37 \pm 0.08$ & $16.55 \pm 1.51$ & $7.41 \pm 1.28$ & $31-1440$ & Wittmann et al. (2012) \\
\hline \multicolumn{6}{|l|}{ Chondrites } \\
\hline CI & $3.87 \pm 0.25$ & 20.87 & 5.37 & 10863 & Tagle and Berlin (2008) \\
\hline $\mathrm{CM}$ & $4.01 \pm 0.30$ & 21.27 & 5.25 & 12396 & Tagle and Berlin (2008) \\
\hline $\mathrm{CO}$ & $3.96 \pm 0.09$ & 19.73 & 5.09 & 13564 & Tagle and Berlin (2008) \\
\hline $\mathrm{CV}$ & $3.76 \pm 0.12$ & 21.26 & 5.55 & 13629 & Tagle and Berlin (2008) \\
\hline $\mathrm{CK}$ & $3.45 \pm 0.40$ & 19.34 & 5.60 & 12518 & Tagle and Berlin (2008) \\
\hline $\mathrm{CR}$ & $3.72 \pm 0.39$ & 20.71 & 5.72 & 13794 & Tagle and Berlin (2008) \\
\hline $\mathrm{CH}$ & $7.65 \pm 0.69$ & 22.86 & 3.02 & 25716 & Tagle and Berlin (2008) \\
\hline $\mathrm{CB}^{\mathrm{a}}$ & $31.22 \pm 7.61$ & 22.27 & 0.69 & 66431 & Tagle and Berlin (2008) \\
\hline $\mathrm{K}$ & $9.72 \pm 5.01$ & 21.85 & 3.28 & 17172 & Tagle and Berlin (2008) \\
\hline $\mathrm{R}$ & $3.99 \pm 0.19$ & 20.53 & 5.09 & 14366 & Tagle and Berlin (2008) \\
\hline $\mathrm{H}$ & $4.38 \pm 0.42$ & 22.07 & 4.54 & 16846 & Tagle and Berlin (2008) \\
\hline $\mathrm{L}$ & $3.22 \pm 0.19$ & 22.67 & 6.40 & 12936 & Tagle and Berlin (2008) \\
\hline LL & $2.64 \pm 0.21$ & 21.19 & 7.78 & 9585 & Tagle and Berlin (2008) \\
\hline EH & $5.79 \pm 0.36$ & 21.04 & 3.59 & 18006 & Tagle and Berlin (2008) \\
\hline EL & $4.77 \pm 1.03$ & 20.18 & 4.33 & 14676 & Tagle and Berlin (2008) \\
\hline \multicolumn{6}{|l|}{ Differentiated achondrites } \\
\hline Howardite & $\sim 0.013$ & $\sim 3.2$ & $\sim 253$ & 65 & Tagle (2004) \\
\hline Eucrites & $\sim 0.024$ & $\sim 3.9$ & $\sim 363$ & 103 & Tagle (2004) \\
\hline Diogenites & $\sim 0.006$ & $\sim 1.8$ & $\sim 368$ & 36 & Tagle (2004) \\
\hline Angrites & $\sim 0.080$ & $\sim 2.9$ & $\sim 43$ & 64 & Tagle (2004) \\
\hline Aubrites & $\sim 1.3$ & $\sim 22$ & $\sim 57$ & 1181 & Tagle (2004) \\
\hline \multicolumn{6}{|l|}{ Primitive achondrites } \\
\hline Winonaites & $\sim 8.3$ & $\sim 47$ & $\sim 5.7$ & 16300 & Tagle (2004) \\
\hline Acapulcoites & $\sim 3.7$ & $\sim 20$ & $\sim 6.1$ & 15799 & Tagle (2004) \\
\hline Lodranites & $\sim 4.5$ & $\sim 18$ & $\sim 10$ & 15053 & Tagle (2004) \\
\hline Brachinites & $\sim 1.2$ & $\sim 12$ & $\sim 13$ & 2934 & Tagle (2004) \\
\hline Ureilites & $0.21-0.24$ & $11-12$ & $49-76$ & 1127 & $\begin{array}{l}\text { Warren et al. (2006), } \\
\text { Tagle (2004) }\end{array}$ \\
\hline Iron meteorites & $379-4000$ & $12-24$ & $0.003-0.058$ & $6.15-17.1 \mathrm{wt} \%$ & Hutchison (2004) \\
\hline
\end{tabular}

${ }^{\mathrm{a}}$ Values for the metallic fraction.

${ }^{\mathrm{b}}$ Unless indicated otherwise.

$76 \mu \mathrm{g} \mathrm{g}^{-1} \mathrm{Ni}$ in "impact glass bomb E-985-101," "porphyritic volcanic rock E-908-73," "glass (fragmental tuff?) E-963-4," and "polymict lithic breccia E-963-14" collected from the crater's surface. However, most impact melt rocks and glass bombs characterized by Gurov and Koeberl (2004), Gurov et al. (2005), and this study contain $<50 \mu \mathrm{g} \mathrm{g}^{-1} \mathrm{Cr},<7 \mu \mathrm{g} \mathrm{g}^{-1}$ of $\mathrm{Co}$, and up to $21 \mu \mathrm{g} \mathrm{g}^{-1}$ of Ni. These compositions are more or less within the range of typical upper continental crustal (UCC) values $\left(\mathrm{Cr}=35-85 \mu \mathrm{g} \mathrm{g}^{-1}, \mathrm{Co}=12-17 \mu \mathrm{g} \mathrm{g}^{-1}\right.$, $\mathrm{Ni}=19-44 \mu \mathrm{g} \mathrm{g}^{-1}$ after Wedepohl [1995] and Taylor and McLennan [1985]) with ratios of e.g., $\mathrm{Ni} / \mathrm{Cr}=0.19$ 0.57 and $\mathrm{Ni} / \mathrm{Co}=0.41-3.3$, compared with $\mathrm{Ni} / \mathrm{Cr}=$ $0.43-0.50$ and $\mathrm{Ni} / \mathrm{Co}=1.6-2.6$ for the upper and lower continental crust and $\mathrm{Ni} / \mathrm{Cr}=2.6-9.7$ and $\mathrm{Ni} / \mathrm{Co}=$ 1923 for chondritic meteorites; Wedepohl 1995; Tagle and Berlin 2008 (Table 6). Nonetheless, the profile plot of the concentrations of various elements versus drill core depth (Fig. 2) indicates that several impactites (e.g., at 318.9, 471.4 mblf and melt rock fragments TM8, 12, 17) are enriched in $\mathrm{Cr}, \mathrm{Ni}$, and $\mathrm{Cu}$, whereas most other impactites and target rocks have essentially 

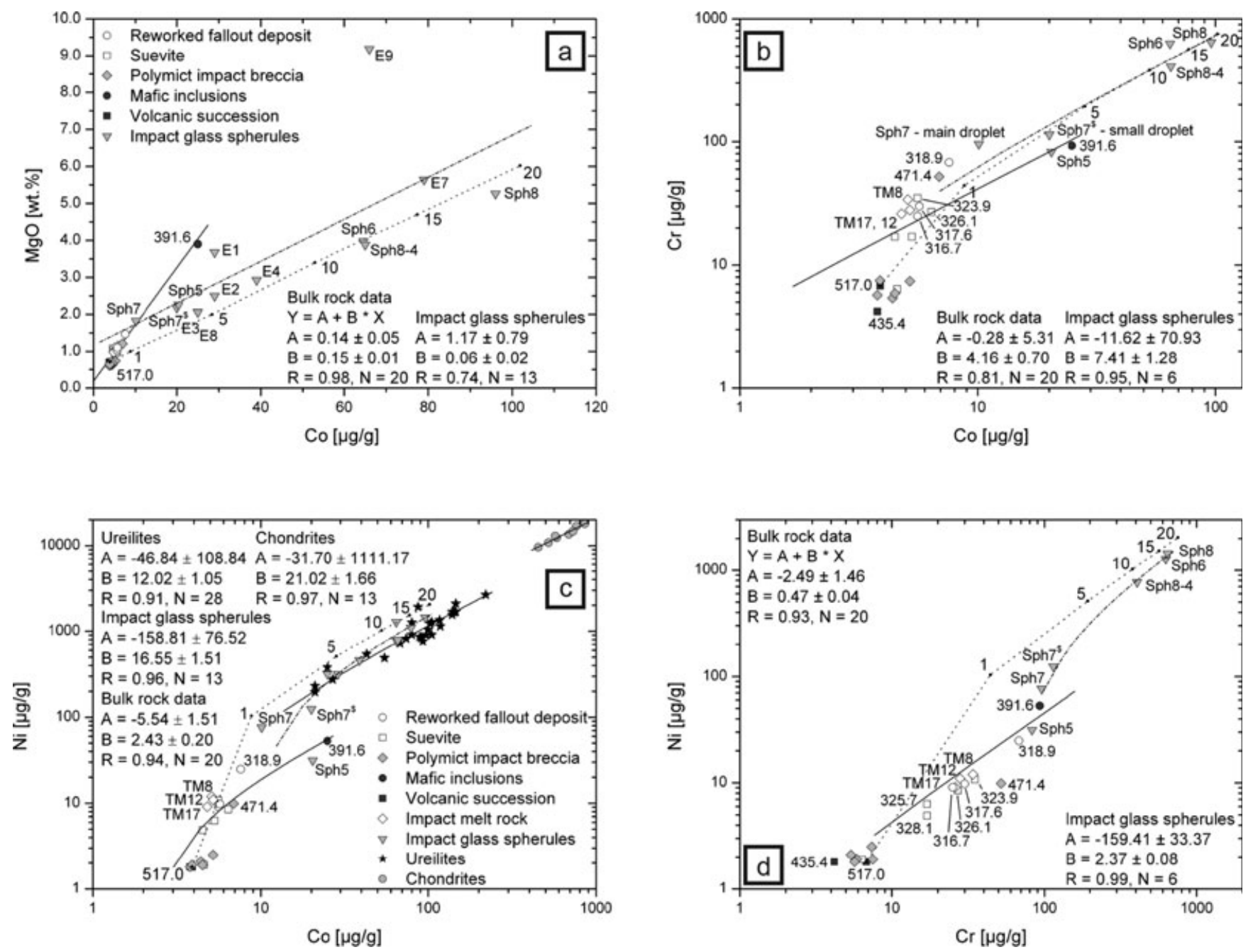

Fig. 5. Plots of (a) $\mathrm{MgO}$ versus $\mathrm{Co}$, (b) $\mathrm{Cr}$ versus $\mathrm{Co}$, (c) $\mathrm{Ni}$ versus $\mathrm{Co}$, and (d) $\mathrm{Ni}$ versus $\mathrm{Cr}$. Impact glass spherule data were determined by LA-ICP-MS and EMPA (Wittmann et al. 2012). Characterized impact spherules come from a terrace deposit of the Enmyvaam River approximately $10 \mathrm{~km}$ southeast of the crater center and the reworked fallout deposit at $317.6 \mathrm{mblf}$. Ureilite data from Warren et al. (2006); chondrite data from Tagle and Berlin (2008). Dotted lines mix modeled contributions of 1 to 20 $\mathrm{wt} \%$ of LL-type ordinary chondrite to the composition of lower rhyolitic ignimbrite at 517.0 mblf. Dash-dot lines reflect linear regression analyses of impact glass spherules, solid lines those calculated for the bulk rock data, ureilites, and chondrites.

the same Co abundance. These observations are in line with those of Va'lter et al. (1982), Gurov and Koeberl (2004), and Gurov et al. (2005), and can at least in part be explained by least squares mixing calculations that add $2.0-13.5 \mathrm{vol} \%$ of mafic inclusions to a rhyolitic ignimbrite target.

While the excellent correlation between $\mathrm{MgO}$ and Co for the drill core impactites (correlation coefficient $\mathrm{R}$ of 0.98 ; Fig. 5a) indicates an essentially indigenous origin of $\mathrm{Co}$, the source of $\mathrm{Cr}$ and $\mathrm{Ni}$ is less evident (correlation coefficients $\mathrm{R}$ with $\mathrm{MgO}<0.50$ ). When plotting the concentrations of $\mathrm{Cr}$ and $\mathrm{Ni}$ versus $\mathrm{Co}$ (Figs. $5 \mathrm{~b}$ and $5 \mathrm{c}$ ), a dichotomous distribution for the composition of the samples becomes apparent, separating the mafic inclusions from all other drill core samples. The mafic inclusion at $391.6 \mathrm{mblf}$, but also the basaltic inclusions at 391.7, 420.6, 420.9, 422.8, and 423.0 mblf (Raschke et al. 2013) display much higher Co concentrations than the reworked fallout deposit, suevite, and impact melt rocks characterized in this study or the Cr-enriched impact glass bomb E-985-101, porphyritic volcanic rockE-908-73, glass E-963-4, and polymict lithic breccia E-963-14 of Gurov et al. (2005). This indicates that the mafic inclusions and similar lithologies are not the only contributors to the moderately siderophile element budget of the drill core impactites. Mixing calculations that use substantial amounts of porphyritic volcanic rock E-908-73 or glass E-963-4 also fail to reproduce the major and trace element abundances of the enriched impactites. 
Va'lter et al. (1982) suggested a common source for the impactite $\mathrm{Ni}$ and $\mathrm{Cr}$ based on the high correlation coefficient (0.80) of the abundances of these two elements as obtained on 40 analyses. These authors concluded that the element enhancement ratios found for the El'gygytgyn impactites compared with the target lithologies resemble most closely the ratios observed in the Novyi Urei meteorite $(\mathrm{Ni} / \mathrm{Co}=2.4-4, \mathrm{Ni} / \mathrm{Cr}=$ $0.25-0.5)$, suggesting the presence of a ureilitic component in the range of approximately $1 \mathrm{vol} \%$. On a plot of $\mathrm{Ni}$ versus $\mathrm{Cr}$ (Fig. 5d), the data obtained in this study correlate well, showing a $\mathrm{Ni} / \mathrm{Cr}$ ratio of $0.47 \pm 0.04(R=0.93, N=20)$ based on the slope of the linear regression line (close to the $\mathrm{Ni} / \mathrm{Cr}$ enhancement ratio of $0.54 \pm 0.2$ of Va'lter et al. 1982). This could be indicative for two-component mixing.

Adolph and Deutsch $(2009,2010)$ and Wittmann et al. (2012) report chemical data obtained by electron microprobe (EMPA) analysis and laser ablation (LA)-ICP-MS on 7 impact glass spherules and spherule fragments recovered from terrace deposits of the Enmyvaam River outside the crater rim, approximately $10 \mathrm{~km}$ southeast of the crater center, and on five spherules from the reworked fallout deposit at 317.6 mblf (Fig. 3). Arguments for the impact origin of the spherules collected outside the crater are presented in Wittmann et al. (2012) and can be summarized as: (1) these spherules are composed of pristine glass, while the target rock clasts in the ICDP drill core indicate pervasive alteration that predates the impact; (2) four of these spherules incorporate accreted lithic debris; (3) the geochemical compositions of these spherules range from rhyolitic to basaltic-andesitic, in large part similar to those of the spherules in samples 316.7 and 317.6 mblf. Because volcanic spherules exclusively form from low-viscosity basaltic melts $\left(\mathrm{SiO}_{2}<52 \mathrm{wt} \%\right)$ and tend to be homogeneous (Heiken et al. 1974), a volcanic origin for the spherules at El'gygytgyn is implausible.

Several of the studied spherules also appear to contain Ni-rich spinel and an admixed ultramafic component (Wittmann et al. 2012); Fig. 4 plots the $\mathrm{MgO}, \mathrm{Cr}, \mathrm{Co}$, and $\mathrm{Ni}$ data for these glass spherules. Although the spherules are compositionally variable from andesitic to rhyolitic, all but one (Sph5 with $\left.\mathrm{Cr}=83 \mu \mathrm{g} \mathrm{g}^{-1}, \quad \mathrm{Co}=20 \mu \mathrm{g} \mathrm{g}^{-1}, \mathrm{Ni}=31 \mu \mathrm{g} \mathrm{g}^{-1}\right)$ are characterized by high to very high $\mathrm{Cr}, \mathrm{Co}$, and $\mathrm{Ni}$ concentrations ( $\mathrm{Cr}$ up to $646 \mu \mathrm{g} \mathrm{g}^{-1}$, Co up to $96 \mu \mathrm{g} \mathrm{g}^{-1}$, Ni up to $1440 \mu \mathrm{g} \mathrm{g}^{-1}$ ) and consistently high $\mathrm{Ni} / \mathrm{Cr}$ of $0.80-2.2, \mathrm{Ni} / \mathrm{Co}$ of $6.2-20$, and $\mathrm{Cr} / \mathrm{Co}$ of 5.7-9.8. On the $\mathrm{MgO}$ versus Co diagram, 5 of the 13 reported impact spherules are characterized by much higher $\mathrm{Co}$ to $\mathrm{MgO}$ ratios than measured for the drill core samples (including those of Raschke et al. 2013), plotting away from the $\mathrm{MgO} / \mathrm{Co}$ correlation line determined for the whole rock impactite concentrations and suggesting an unsampled or uncharacterized contributing source (Fig. 5a). On a plot of $\mathrm{Ni}$ versus $\mathrm{Co}$, the correlation coefficient determined for the linear regression line between these 13 samples is excellent (0.96), with a $\mathrm{Ni} / \mathrm{Co}$ ratio (represented by the slope of the regression line) of $16.55 \pm 1.51$ (Fig 4c). For the five glass spherules of the reworked fallout deposit at 317.6 mblf (Wittmann et al. 2012), additionally characterized for their $\mathrm{Cr}$ content, excellent correlations between $\mathrm{Cr}$, Co, and $\mathrm{Ni}$ are also observed $(R>0.95$; Figs. 5b and 5d). These concentrations and ratios (summarized in Table 6) cannot be derived from upper or lower continental crustal values $(\mathrm{Cr}=$ $35-228 \mu \mathrm{g} \mathrm{g}^{-1}, \mathrm{Co}=12-38 \mu \mathrm{g} \mathrm{g}^{-1}, \mathrm{Ni}=19-99 \mu \mathrm{g} \mathrm{g}^{-1}$; Wedepohl 1995) or even a component geochemically close to Earth's mantle $\left(\mathrm{Cr}=2520 \mu \mathrm{g} \mathrm{g}^{-1}\right.$, $\mathrm{Co}=102 \mu \mathrm{g} \mathrm{g}^{-1}, \mathrm{Ni}=1860 \mu \mathrm{g} \mathrm{g}^{-1}$, with $\mathrm{MgO}=36.8$ $\mathrm{wt} \%$; Palme and O'Neill 2004), unless strongly fractionated. The $\mathrm{Ni} / \mathrm{Cr}$ and $\mathrm{Cr} / \mathrm{Co}$ ratios determined by linear regression for the impact spherules are within the compositional ranges of certain chondrites and primitive achondrites (Table 6). The determined $\mathrm{Ni} / \mathrm{Co}$ for the impact spherules is intermediate between the ratios determined for ureilites $(12.02 \pm 1.05, R=0.91$ for 28 data points by Warren et al. 2006) and brachinites (approximately 12) and those of chondrites $(21.02 \pm 1.66, R=0.97$ for 13 chondrite types averaged in Tagle and Berlin 2008), lodranites, and acapulcoites (approximately 19-20; Table 6).

\section{Platinum Group Element Abundances}

The 12 PGE and Au abundances determined in this study by NiS-ICP-MS are low (over $50 \%$ of the measured Ir concentrations fall below the limit of quantification) to slightly elevated compared with average UCC values - $\mathrm{Ir}=0.02 \mathrm{ng} \mathrm{g}^{-1}, \mathrm{Ru}=$ $0.21 \mathrm{ng} \mathrm{g}^{-1}, \mathrm{Pt}=0.51 \mathrm{ng} \mathrm{g}^{-1}, \mathrm{Rh}=0.06 \mathrm{ng} \mathrm{g}^{-1}, \mathrm{Pd}=$ $0.52 \mathrm{ng} \mathrm{g}^{-1}$, and $\mathrm{Au}=2.5 \mathrm{ng} \mathrm{g}^{-1}(\mathrm{Rh}$ and $\mathrm{Au}$ from Wedepohl 1995; other PGEs from Peucker-Ehrenbrink and Jahn 2001; Table 4). Iridium contents for these impactites vary from 0.046 to $0.262 \mathrm{ng} \mathrm{g}^{-1}$ (Table 4), in the same order of magnitude as the range measured by Gurov and Koeberl (2004) for two impact melt rocks (EL 669-8 and 10) and a glass bomb (EL 689) ( $\mathrm{Ir}=0.024 \pm 0.010$ to $\left.0.111 \pm 0.021 \mathrm{ng} \mathrm{g}^{-1}\right)$. While the enrichment is more obvious for $\mathrm{Ir}, \mathrm{Ru}, \mathrm{Pt}$, and $\mathrm{Rh}$, the values for $\mathrm{Pd}$ and $\mathrm{Au}$ do not appear equally elevated. This observation could be linked to the higher relative mobility of $\mathrm{Au}$ and Pd compared with the other PGEs (e.g., Evans et al. 1993), or it could be an inherent characteristic of the PGE enrichment. While correlation 


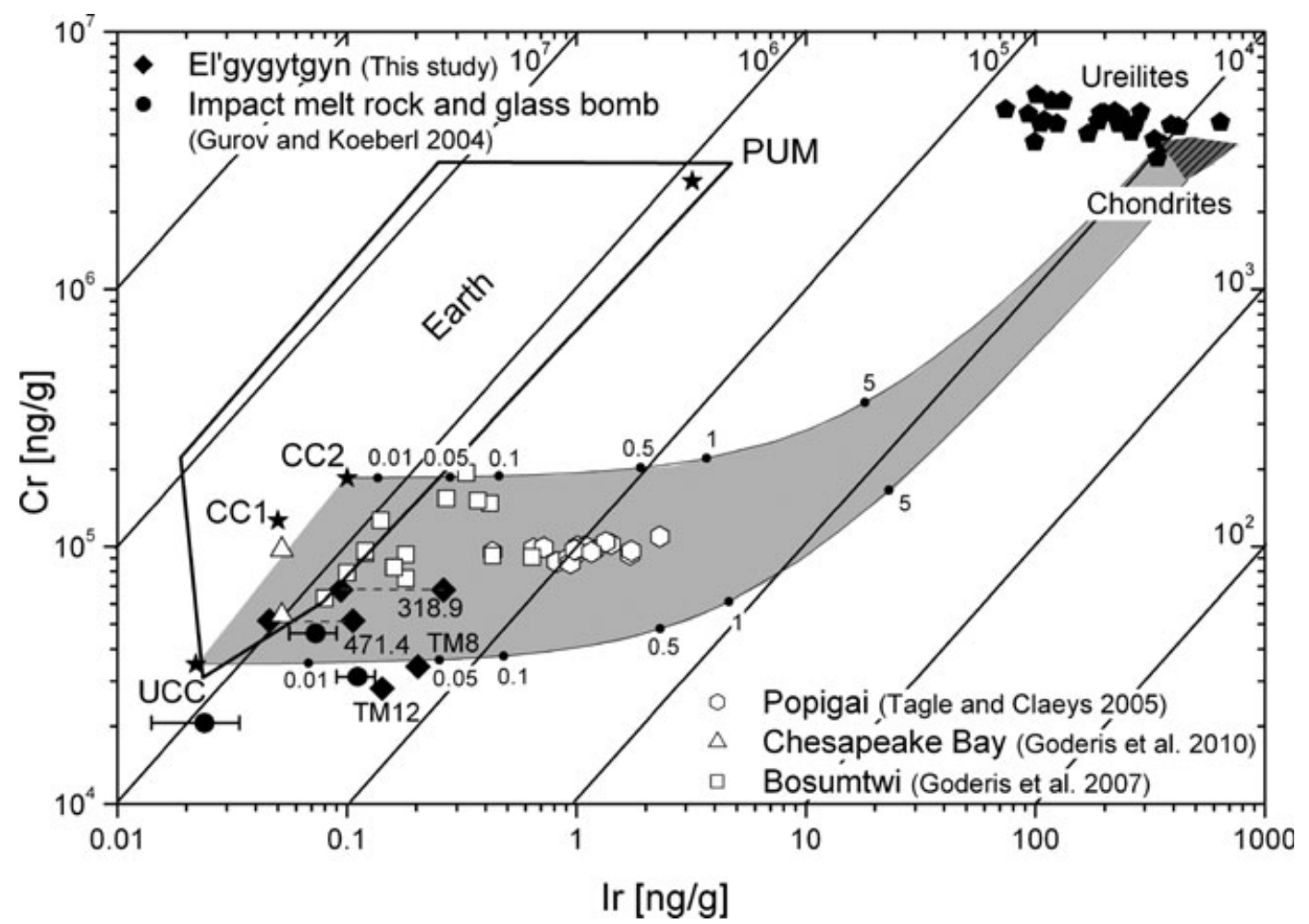

Fig. 6. Double logarithmic plot of the Cr versus Ir concentration of the El'gygytgyn impactites compared with the Cr/Ir ratio in various terrestrial lithologies, chondrites, and ureilites (adapted after Tagle and Hecht 2006; ureilite data from Warren et al. 2006). Values measured at the Bosumtwi, Chesapeake Bay, and Popigai impact structure are presented for comparison (Tagle and Claeys 2005; Goderis et al. 2007, 2010). The gray field indicates the most likely mixing trajectory between chondritic projectiles and common terrestrial targets. Next to the data measured in this study, also data for impact melt rocks and a glass bomb of Gurov and Koeberl (2004) are plotted. UCC = upper continental crust; CC = continental crust; CC1 = Wedepohl (1995); CC2 = Taylor and McLennan (1985); PUM = primitive upper mantle (McDonough and Sun 1995).

coefficients between $\mathrm{Ir}, \mathrm{Ru}, \mathrm{Pt}$, and $\mathrm{Rh}$ vary from good to excellent ( $R$ between 0.67 and 0.99 ), they correlate substantially less with $\mathrm{Pd}$ and $\mathrm{Au}(R$ between 0.26 and $0.70)$ and with $\mathrm{Cr}$, Co, and $\mathrm{Ni}(R=0.02-0.47)$. However, the correlations between $\mathrm{Cr}$, $\mathrm{Co}$, and $\mathrm{Ni}$ are excellent ( $R$ between 0.82-0.94). In several impact-crater studies, strong correlations between moderately and highly siderophile elements have been used to suggest a common origin and to exclude mafic or ultramafic contributions, as well as significant postimpact fractionation or remobilization (e.g., Palme 1980; Morgan and Wandless 1983). At El'gygytgyn, the situation appears more complex because based on least squares mixing calculations, the mafic inclusions could have contributed $2.0-13.5 \mathrm{vol} \%$ to the reworked fallout deposit at 318.9 mblf, the polymict impact breccia at 471.4 mblf, and the three impact melt rock fragments.

The reworked fallout deposit at 318.9 mblf (Fig. 1e) shows the highest $\mathrm{Cr}$ and $\mathrm{Ni}$ values, and has the highest $\mathrm{Ir}, \mathrm{Ru}, \mathrm{Pt}$, and $\mathrm{Rh}$ values for one replicate analysis (but not $\mathrm{Co}, \mathrm{Pd}$, and $\mathrm{Au}$; Table 4). Elevated PGE concentrations compared with the average continental crust and the local target background signal (with mafic inclusion 391.6 as the most mafic possible contributor in this study) are also measured for impact melt rocks TM8 and $12\left(0.142-0.203 \mathrm{ng} \mathrm{g}^{-1}\right.$ Ir) and the lower polymict impact breccia at 471.4 mblf (0.046$0.106 \mathrm{ng} \mathrm{g}^{-1}$ Ir; Fig. 1a), concurrent to the anomalous moderately siderophile element $(\mathrm{Cr}, \mathrm{Co}$, and $\mathrm{Ni}$ ) concentrations. The sole exception is the mafic inclusion at 391.6 mblf, where the moderately siderophile element enrichment is not accompanied by significantly elevated PGE abundances. The reported variability for different sample aliquots suggests a heterogeneous distribution of the PGE carrier in the El'gygytgyn impactites. As reported in previous studies (e.g., Hall and Pelchat 1994; Tagle and Claeys 2005), processing larger sample volumes $(>10 \mathrm{~g})$ can compensate for these nugget effects, suggesting that the larger sample aliquot analyses are more likely to be representative for the respective drill core intervals.

On a double-logarithmic plot of $\mathrm{Cr}$ versus $\mathrm{Ir}$ (Fig. 6), the PGE-enriched impactites follow mixing lines that are typical for an admixture of chondritic projectile material (calculated based on average CI carbonaceous chondrites; Tagle and Berlin 2008) to 

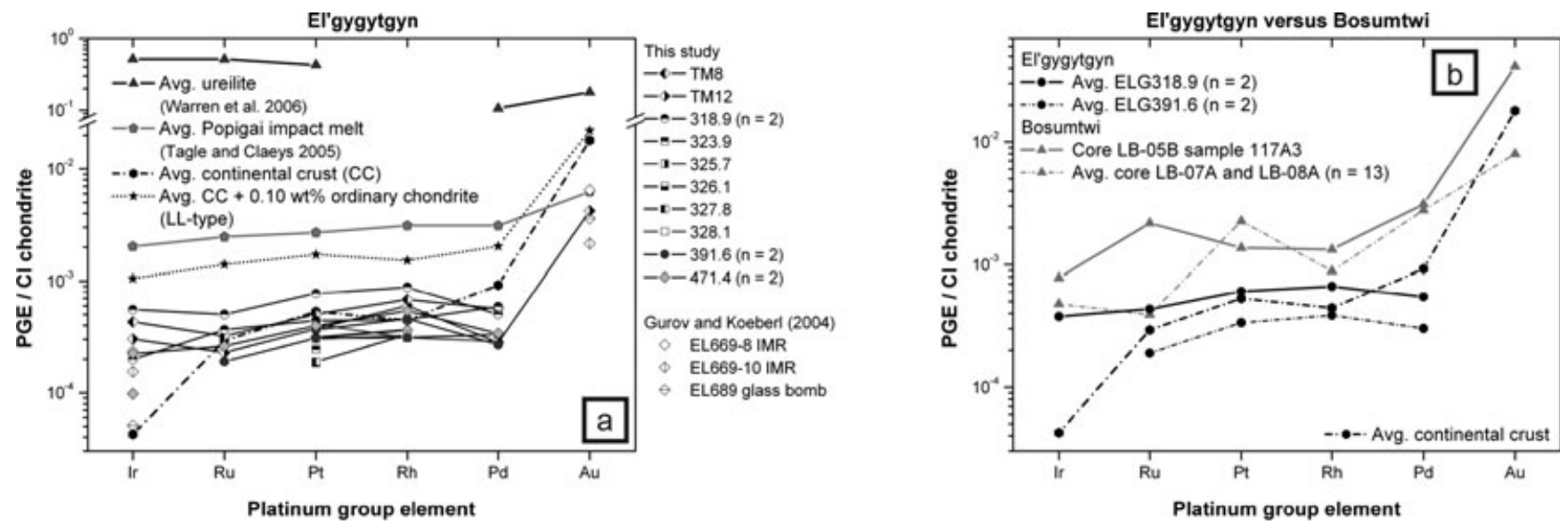

Fig. 7. CI-normalized logarithmic plot of the PGE and Au concentrations of a) the El'gygytgyn ICDP drill core samples and melt rock fragments characterized in this study, in comparison with the average continental crust, the impact melt rocks and glass bomb measured for Ir and Au by Gurov and Koeberl (2004), the average Popigai impact melt (Tagle and Claeys 2005), $0.10 \mathrm{wt} \%$ of LL-type ordinary chondrite added to the average continental crust, and the average of ureilites (Warren et al. 2006); b) the ICDP drill core samples from the reworked fallout deposit 318.9 mblf and the mafic inclusion 391.6 mblf of El'gygytgyn in comparison with the averaged LB-07A and LB-08A ICDP drill cores and uppermost impact fallback layer LB-05117A3 of Bosumtwi (Goderis et al. 2007). Values for the continental crust are from Peucker-Ehrenbrink and Jahn (2001); $\mathrm{Rh}$ and $\mathrm{Au}$ values come from Wedepohl (1995); chondrite values are from Tagle and Berlin (2008). The PGEs are plotted from left to right in order of decreasing condensation temperature.

terrestrial crustal rocks. For comparison, data for impactites from the Bosumtwi, Chesapeake Bay, and Popigai impact structures are also shown (data from Tagle and Claeys 2005; Goderis et al. 2007, 2010). The Popigai impactites contain approximately $0.2 \mathrm{wt} \%$ of an ordinary chondritic component (Tagle and Claeys 2005) and plot along a path that tracks the admixture of chondritic material into the continental crust. In contrast, the ICDP-Eyreville drill core samples of the Chesapeake Bay impact crater do not record a distinct meteoritic component (Goderis et al. 2010) and fall within the terrestrial ("Earth") field. In the case of Bosumtwi, where a mafic target rock component with varying $\mathrm{Cr}$ and $\mathrm{Ir}$ contributions obscures the meteoritic component, up to $0.1 \mathrm{wt} \%$ of extraterrestrial material appears dissolved in the suevites of the ICPD cores (Goderis et al. 2007). The El'gygytgyn impactites measured in Gurov and Koeberl (2004) and in this study display only minor PGE enrichment and have a background composition close to upper continental crust (UCC) values (reflected by EL689 glass bomb of Gurov and Koeberl 2004). For a more detailed description of the data used for terrestrial rocks in this plot, see the compilation of literature data in Tagle and Hecht (2006). On a CI carbonaceous chondrite-normalized logarithmic scale, with the PGEs and $\mathrm{Au}$ plotted according to decreasing condensation temperatures, all measured El'gygytgyn impactites show comparable, relatively nonfractionated (i.e., flat) chondritic patterns, although similarities to the average continental crust are also evident (Fig. 7).

\section{Osmium Isotope Ratios}

To investigate the nature of the PGE enrichment, Os isotope ratios were measured in three reworked fallout deposit samples (316.7, 317.6, and $318.9 \mathrm{mblf})$, the mafic inclusion at 391.6 mblf, and an impact melt rock fragment (TM17). The presence of a mantle component, such as an ultramafic rock, can apparently be ruled out for most of these El'gygytgyn impactites based on major and trace element abundances (all $\mathrm{Fe}_{2} \mathrm{O}_{3} \leq 3.6 \mathrm{wt} \%$ and all $\mathrm{MgO} \leq 1.5 \mathrm{wt} \%$ ), with exception of the mafic inclusion at 391.6 mblf. These ${ }^{187} \mathrm{Os} /{ }^{188} \mathrm{Os}$ ratios can be interpreted as approximate to the initial ratios because the age of the El'gygytgyn impact crater is very young (3.6 Ma; Layer 2000); moreover, the ${ }^{187} \mathrm{Re} /{ }^{188}$ Os ratios were not measured in this study. Although the measured Os concentrations are low $\left(\leq 0.068 \mathrm{ng} \mathrm{g}^{-1}\right)$, all reworked fallout deposit samples and the melt rock have much lower ${ }^{187} \mathrm{Os} /{ }^{188} \mathrm{Os}$ ratios (0.148-0.239) than the mafic inclusion at $391.6 \mathrm{~m}$ $\left({ }^{187} \mathrm{Os} /{ }^{188} \mathrm{Os}\right.$ of 2.8$)$. Considering that this inclusion likely has a Paleocene origin and contains low Os abundances, high $\mathrm{Re} / \mathrm{Os}$ values are likely. In agreement with the siderophile abundance results, the bottom of the reworked fallout deposit at 318.9 mblf displays the highest PGE anomaly (68 $\mathrm{pg} \mathrm{g}^{-1}$ Os) and lowest ${ }^{187} \mathrm{Os} /{ }^{186} \mathrm{Os}$ ratio $(0.148 \pm 0.001$; Table 5$)$. The strongly 


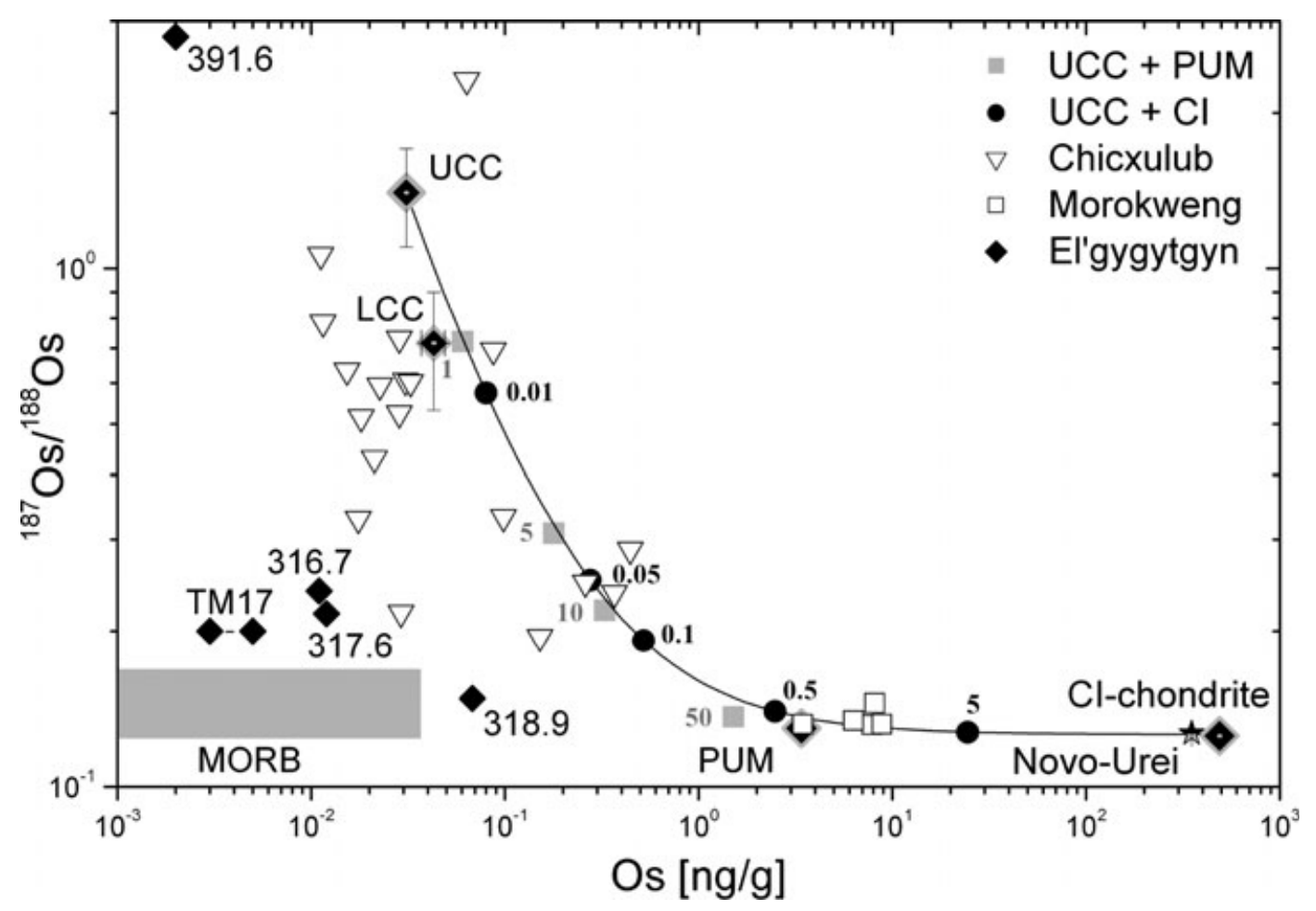

Fig. 8. ${ }^{187} \mathrm{Os} /{ }^{188} \mathrm{Os}$ isotope ratios versus Os concentrations $\left(\mathrm{ng} \mathrm{g}^{-1}\right)$ for various terrestrial rocks, CI carbonaceous chondrites (Wasson and Kallemeyn 1988), averaged ureilites (Warren et al. 2006; Rankenburg et al. 2007), and impactites of the Morokweng (Koeberl et al. 2002), Chicxulub (Gelinas et al. 2004), and El'gygytgyn impact structures. The curve represents the calculated mixing line between CI chondrite values and the upper continental crust (UCC) (Os $=0.031 \mathrm{ng}^{-1}$ and ${ }^{187} \mathrm{Os} /{ }^{188} \mathrm{Os}=1.4$; Peucker-Ehrenbrink and Jahn 2001). Percentages of projectile material mixed into hypothetical impact melt are shown as a line with black dots $(0.01$ to $5 \mathrm{wt} \%)$. The mixing trajectory between UCC and primitive upper mantle (PUM) $\left(\mathrm{Os}=3 \mathrm{ng} \mathrm{g}^{-1}\right.$ and ${ }^{187} \mathrm{Os} /{ }^{188} \mathrm{Os}=0.125$; McDonough and Sun 1995; Meisel et al. 2001) is indicated by solid squares (1 to 50 wt $\%$ ) only. Adapted after Tagle and Hecht (2006).

differing Os isotope ratios measured for (1) impact melt rock fragments and reworked fallout deposits, and (2) the basaltic inclusions also characterized by low Os concentrations, indicate the presence of an additional component - with low Os isotope ratios and a relatively flat CI-normalized, logarithmic PGE signature.

Figure 7 plots ${ }^{187} \mathrm{Os} /{ }^{188} \mathrm{Os}$ isotope ratios versus Os concentrations for various terrestrial rocks (including upper [UCC] and lower [LCC] continental crust and primitive upper mantle [PUM]), CI chondrites (Wasson and Kallemeyn 1988), and the Morokweng (Koeberl et al. 2002), Chicxulub (Gelinas et al. 2004), and El'gygytgyn impactites (this study). While the impactites of the Morokweng structure lie close to a mixing line between a hypothetical CI chondritic impactor and the UCC, the Chicxulub and El'gygytgyn impactites show much lower Os concentrations and higher ${ }^{187} \mathrm{Os} /{ }^{188} \mathrm{Os}$ ratios. With an average continental crustal target lithology composition-and no apparent contribution from mantle material or young, mantle-derived mafic rocks - the high Os and low ${ }^{187} \mathrm{Os} /{ }^{188} \mathrm{Os}$ ratios of the Morokweng impactites can be attributed to an extraterrestrial component (Koeberl et al. 2002). For Chicxulub, the samples reflect a mixing trend between the continental crust and a meteoritic component (Gelinas et al. 2004). While most samples have values not substantially different from those of the continental crust (Fig. 8), the ones with higher Os and lower ${ }^{187} \mathrm{Os} /{ }^{188} \mathrm{Os}$ ratios most likely reflect the presence of an extraterrestrial component below $0.1 \mathrm{wt} \%$, rather than the admixture of $10 \mathrm{wt} \%$ mafic rock (Gelinas et al. 2004). For El'gygytgyn, the difference in Os isotopic composition between the mafic contributor(s) and the enriched impactites reflects the presence of uncharacterized or unsampled target rock lithologies and/or a meteoritic component.

\section{DISCUSSION}

\section{Meteoritic Component at El'gygytgyn: Diluted, but Distinct?}

The amount of meteorite contribution needed to detect, and eventually identify the projectile in an 
impactite depends on several parameters: (1) the proportion of siderophile elements in the projectile; (2) the proportion of PGEs in the target lithologies; (3) the homogeneity of the projectile material distribution; and (4) the analytical method applied to identify the extraterrestrial component (e.g., Palme 1980; Tagle and Hecht 2006; Koeberl 2007; Goderis et al. 2012).

Projectiles enriched in highly siderophile elements, i.e., chondrites, stony-iron, and iron meteorites, are more likely to induce a strong enrichment (e.g., more than $0.1 \mathrm{wt} \%$ of bulk meteoritic contribution) in impactites that is discernable from background target lithology siderophile element contents. Whereas chondrites are accompanied by elevated $\mathrm{Cr}$ abundances of $2575-3810 \mu \mathrm{g} \mathrm{g}^{-1}$ and $\mathrm{Ni} / \mathrm{Cr}$ ratios that vary between roughly 2 and 7 (Tagle and Berlin 2008), iron meteorites contain approximately two orders of magnitude less $\mathrm{Cr}$ (Buchwald 1975). Consequently, iron meteorites display much higher $\mathrm{Ni} / \mathrm{Cr}$ or lower $\mathrm{Cr} / \mathrm{Co}$ ratios (up to three orders of magnitude), although exceptions occur (e.g., silicate-rich nonmagmatic iron meteorites; Tagle et al. 2009; Goderis et al. 2009; Table 6).

The situation is less transparent for PGE-poor impactors, such as differentiated achondrites howarditeseucrites-diogenites, aubrites, and angrites. In the absence of clear $\mathrm{Ni}, \mathrm{Co}$, and $\mathrm{PGE}$ enrichments that are accompanied by elevated $\mathrm{Cr}$ values (and low $\mathrm{Ni} / \mathrm{Cr}$ and high $\mathrm{Cr} / \mathrm{Co}$ ratios) in impactites, (differentiated) achondritic impactors have been suggested (Koeberl 2007) (Table 6). However, it is often difficult to completely rule out an indigenous (ultra)mafic origin for elevated $\mathrm{Cr}$ concentrations. Terrestrial impact structures with little or no enrichment in siderophile elements include Nördlinger Ries, Mistastin, West Clearwater, Saint Martin, Chesapeake Bay, and Manicouagan (Morgan et al. 1975, 1979; Palme et al. 1978, 1981a; Palme 1982; Schmidt and Pernicka 1994; Goderis et al. 2010). For most of these craters, the precise type of impactor has not been constrained so far. Although not all types of projectiles are well characterized or even known (e.g., comets)meteorite collections sample a subset of the existing cosmic material (e.g., Jenniskens et al. 2009) —some of these structures have tentatively been linked to the impact of achondritic projectiles. The only impact structures where strong cases for achondrite impactors have been presented are Lake Nicholson and Strangways that were likely produced by olivine-rich achondrites, judging from the nature of the PGE enrichments (Wolf et al. 1980; Morgan and Wandless 1983).

In homogenous and continuous impact-melt sheets, where the highest projectile contributions generally occur, it is possible to detect, and eventually characterize, minute $(\leq 0.10 \mathrm{wt} \%)$ proportions of a chondritic projectile, sometimes even in the case of a PGE-enriched target (Tagle and Hecht 2006). However, these approaches are not always applicable to less homogenized impactites, as for example, the impact breccias from Bosumtwi, in which target rock contributions mask the meteoritic component (Goderis et al. 2007).

A meteoritic component appears to be present in several El'gygytgyn impactites. Based on the major and trace element abundances, a major contribution $(>15$ vol\%) from a mafic target component (known from regional outcrops and fragments in the drill core) is inadequate to explain all features observed for the analyzed El'gygytgyn impactites. This suggests that these impactites were mainly derived from the upper $620 \mathrm{~m}$ thick volcanic succession of rhyolite, dacites, and andesites (cf. Wittmann et al. 2012). Unfortunately, these target lithologies were not characterized for their PGE contents in this study. Nonetheless, the presence of an extraterrestrial component in the El'gygytgyn impactites is confirmed based on (1) the moderately siderophile trace element abundances and nonterrestrial ratios measured for the recovered impact glass spherules and spherule fragments (Wittmann et al. 2012) (Figs. 2 and 4), (2) the double-logarithmic plot of $\mathrm{Cr}$ versus Ir concentrations (Fig. 6), (3) the CI-normalized PGE and $\mathrm{Au}$ signature (Fig. 7a), and (4) the Os isotopic signature (Fig. 8). An additional, and perhaps even less ambivalent, argument is presented by the nonterrestrial $\mathrm{Cr}$ isotopic composition of an impact glass sample from El'gygytgyn that Foriel et al. (2013) determined.

In terms of whole rock analyses, a bulk meteoritic component of up to $0.05 \mathrm{wt} \%$ (of hypothetical bulk CI carbonaceous chondrite) can be deduced from the double logarithmic plot of the $\mathrm{Cr}$ versus $\mathrm{Ir}$ concentration (Fig. 6), with a starting point that is close to the upper continental crust of Wedepohl (1995), for the highest projectile contributions, measured in impact melt rock fragment TM8 and reworked fallout deposit 318.9. As can be observed on this plot, the proportions of meteoritic component (nominal CI chondrite) in the impactites of El'gygytgyn are higher than the values reported for the ICDP-Eyreville drill core of the Chesapeake Bay impact structure. The amount of meteoritic component in El'gygytgyn impactites appears comparable to those of the Chicxulub impactites, but lower than those of the Bosumtwi ICDP drill core (approximately $0.1 \mathrm{wt} \%$ ) and Popigai impact melt (approximately $0.2 \mathrm{wt} \%$ ) (Figs. 6, 7, and 8 and references therein). The very diluted meteoritic signature at El'gygytgyn is likely only discernible owing to the relatively low background PGE concentrations in the target lithologies. When comparing the CI-normalized PGE and Au pattern of El'gygytgyn to, for instance, that 
of the Popigai impact melt (Fig. 7a) (Tagle and Claeys 2005), the average PGE signature in the El'gygytgyn impactites appears to share characteristics of both the impacted meteorite and the target lithologies.

In terms of the Re-Os isotopic system, the background signal measured for the mafic inclusion 391.6 (with large blank correction) plots more closely to upper continental crustal values. However, the reworked fallout deposit samples and the impact melt rock fragment probably reflect the presence of a diluted meteoritic component. Model mixing calculations indicate the absence of strong target rock contributions to the Os budget and the presence of $0.05-0.10 \mathrm{wt} \%$ of bulk CI carbonaceous chondrite material in reworked fallout deposit sample 318.9 (Fig. 8), comparable to the amount of cosmic contribution deduced from the Cr-Ir plot (Fig. 6). Although the Os isotope ratio method is highly sensitive for the detection of a projectile component, it is currently not possible to obtain any specific information about the projectile type with this method.

\section{Distribution of Projectile Material}

In order of increasing projectile contribution, this study detected a meteoritic component in (1) the lower polymict lithic breccia, (2) two impact melt fragments, and (3) at the bottom of the fallout deposit. The latter is associated with impact glass spherules, some with Ni-rich spinel and possibly strongly enriched in a meteoritic component based on their moderately siderophile element contents and ratios (Wittmann et al. 2012). As expected, the impact melt rocks - suggested to have the highest probability to contain a meteoritic component (Va'lter et al. 1982) - contain fairly reproducible abundances of $\mathrm{Cr}, \mathrm{Co}, \mathrm{Ni}$, and $\mathrm{Ir}$ (on the order of $100-200 \mathrm{ng} \mathrm{g}^{-1}$; Table 4). Less evident is the slight increase in moderately siderophile and PGE abundances determined for the lower polymict impact breccia. This breccia may consist of debris that was picked up during the radial transport over $2-6 \mathrm{~km}$ from near the upper wall of the transient cavity to the current location on top or on the flank of the collapsed central uplift (Wittmann et al. 2012).

Sample 318.9, located in close proximity to the boundary between suevite and reworked fallout deposits at 319.4 mblf, has the highest abundance of impact spherules of approximately $1.4 \mathrm{~cm}^{-2}$ among the three samples from the reworked fallout deposit (Wittmann et al. 2012), and it contains the strongest impactor signature. In these respects, it is reminiscent of Bosumtwi's uppermost impact fallback layer, a $30 \mathrm{~cm}$ thick, size-sorted unit that caps the impactite deposits and contains microtektite-like spherules, accretionary lapilli and shocked quartz in its uppermost $10 \mathrm{~cm}$ (Koeberl et al. 2007). The observed PGE pattern for this fallback layer is flatter and more similar to that expected for a chondritic contamination compared with the Bosumtwi samples, which are dominated by mafic to ultramafic target rock components (Goderis et al. 2007) (Fig. 7b). It appears that some of the impact glass spherules at El'gygytgyn record a relatively large contribution of meteoritic material based on their $\mathrm{MgO}$, $\mathrm{Cr}, \mathrm{Co}$, and $\mathrm{Ni}$ abundances and ratios (Wittmann et al. 2012) (Fig. 4). In several impact structures, including the Nördlinger Ries (Pernicka et al. 1987) and Rochechouart (S. Goderis, unpublished data), graded deposits overlying suevites contain a meteoritic component. However, spherules were only found in such deposits at Bosumtwi and El'gygytgyn (Koeberl et al. 2007; Wittmann et al. 2012).

\section{Possible Types of Projectile}

A prominent $\mathrm{Cr}$ and less pronounced $\mathrm{Ni}$ and $\mathrm{Ir}$ enrichment combined with the observed siderophile interelement ratios (e.g., $\mathrm{Ni} / \mathrm{Cr}, \mathrm{Cr} / \mathrm{Ir}$, etc.), led several authors to suggest a ureilitic achondrite as possible impactor for El'gygytgyn (e.g., Va'lter et al. 1982; Gurov and Koeberl 2004). The moderately siderophile element contents, Os isotope ratios, and nonfractionated CI-normalized PGE pattern with possible slight depletion in $\mathrm{Pd}$ and $\mathrm{Au}$ measured for several whole rock impactites of the ICDP-El'gygytgyn lake 1C drill core could be interpreted to record an ureilite impactor. Moreover, the $\mathrm{Cr}$ isotopic composition of an impact glass sample is inconsistent with known carbonaceous chondrites, but is within analytical error of eucrites and ordinary chondrites, and nearly identical to the reported values for ureilites (Foriel et al. 2013).

However, provided elemental fractionation (e.g., during volatilization and/or oxidation) and a strongly heterogeneous impactor are precluded, the moderately siderophile element contents and their ratios in the characterized impact glass spherules and spherule fragments, recovered from the reworked fallout deposits and terrace deposits of the Enmyvaam River outside the crater rim, are not characteristic of ureilites. After exclusion of most types of differentiated achondrites (HED, angrites, and aubrites) and iron meteorites based on the $\mathrm{Ni} / \mathrm{Cr}, \mathrm{Ni} / \mathrm{Co}$, and $\mathrm{Cr} / \mathrm{Co}$ ratios and their generally fractionated CI-normalized PGE patterns, ordinary chondrites remain as the most likely types of projectiles, followed by several types of primitive achondrites (Table 6).

Least squares mixing calculations (Korotev et al. 1995) were used to model the major and minor element compositions plus $\mathrm{Cr}, \mathrm{Co}$, and $\mathrm{Ni}$ concentrations of 
four impact spherules (normalized to $100 \mathrm{wt} \%$ with standard deviations recalculated to relative $\%$, which were used as weighting factors) recovered from the reworked fallout deposits at 317.6 mblf. Whole rock compositions of rhyolitic ignimbrite samples 517.0 and 435.4 mblf, mafic inclusion $391.6 \mathrm{mblf}$, and average compositions of ordinary chondrites (Hutchison 2004) were used as additional mixing components in the models. Successful mixing calculations are presented in Table 7. These results indicate that the composition of the impact glass spherules Sph5, 6, 7, and 8 can be represented by a dominant portion of rhyolitic ignimbrite target rocks $(>80 \%)$ and $0.50-18 \mathrm{wt} \%$ of admixed ordinary chondrite, most likely type-LL. Ignimbrite sample 517.0 mblf was found to be the only required target rock component for all successful mixing calculations. For Sph6, effective mixing results were obtained with additions of $1.0-8.0 \mathrm{wt} \%$ of upper ignimbrite sample 435.4 mblf. However, this target rock component is not necessary to produce a successful mixture between lower ignimbrite sample 517.0 and approximately $13 \mathrm{wt} \%$ ordinary chondrite. Consistently, mixtures with the LL-chondrite average composition yielded the best melt mixing results, as expressed by the smallest reduced sum of residual squares $\left(\chi^{2} / v\right.$; with $\chi^{2}$ being the sum of least squares, and $v$ the number of major, minor, and trace elements minus the number of components, i.e., rock compositions used for the mixing calculation) compared with mixtures with L- and H-chondrite, Lodran, or Acapulco (Tables A1 and 7). It is also noteworthy that the mixing results for Sph6 and Sph $8\left(\chi^{2} / v\right.$ of 2.6 and 1.6) are far more reliable than those for $\operatorname{Sph} 5\left(\chi^{2} / v\right.$ of 5.6) and (the main part of droplet aggregate-spherule) $\operatorname{Sph} 7\left(\chi^{2} / v\right.$ of 7.5$)$. At the same time, contributions of $0.05 \mathrm{wt} \%$ of LL-type chondritic material led to a significant systematic improvement of the whole rock mixing calculations for the reworked fallout deposit at 318.9 mblf and the melt rock fragments $\left(\chi^{2} / v\right.$ below 1$)$. Figure 4 models contributions of $1-20 \mathrm{wt} \%$ of LL-type ordinary chondrite to the composition of the lower rhyolitic ignimbrite at 517.0 mblf. On the $\mathrm{MgO}$ versus $\mathrm{Co}$ plot (Fig. 5a), the modeled contributions follow a line with a slope almost identical to the result of linear regression analysis for the characterized impact glass spherules and spherule fragments (slope $B=0.06 \pm 0.02, R=0.74$, $N=13$ ). On a diagram of $\mathrm{Ni}$ versus $\mathrm{Cr}$ (Fig. $5 \mathrm{~d}$ ), the dash-dot line resulting from linear regression slightly plots away from the modeled mixing line, suggesting larger relative contributions from lithologies such as the basaltic inclusions between 420 and 423 mblf (Raschke et al. 2013) in spherules Sph5 and Sph7. On this diagram, it also becomes apparent that, while most polymict impact breccias (with exception of 471.4) plot

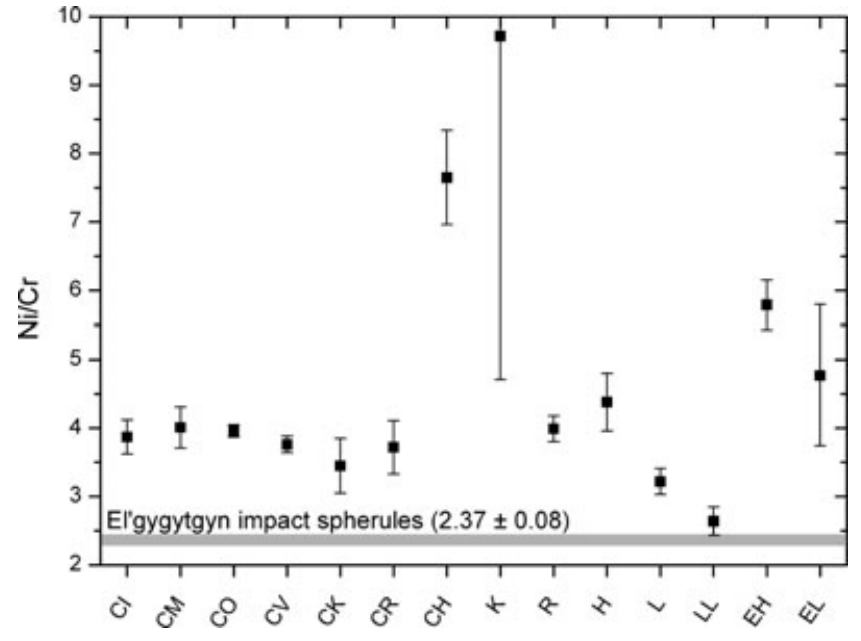

Fig. 9. Plot showing the mean $\mathrm{Ni} / \mathrm{Cr}$ ratios of various types of chondrites (CI, CM, CO, CV, CK, CR, CH, K, R, H, L, LL, EH, EL) with associated error bars (data from Tagle and Berlin 2008). The $\mathrm{Ni} / \mathrm{Cr}$ ratio calculated for the El'gygytgyn impact glass spherules $(N=6)$ by linear regression analysis (indicated by light gray bar) is only consistent with LL-type ordinary chondrites.

close to the lower rhyolitic ignimbrite at $517.0 \mathrm{mblf}$, most reworked fallout deposits and suevites, and several impact melt rocks show compositions characteristic for the admixture of minor amounts of basaltic inclusions and/or ordinary chondrite. Similarly, on a plot of $\mathrm{Ni}$ versus $\mathrm{Co}$ (Fig. 5c), the slightly subchondritic $\mathrm{Ni} / \mathrm{Co}$ ratio of $16.55 \pm 1.51(R=0.96, N=13)$ could reflect shallowing of the linear regression slope through the composition of Sph5 and Sph7, due to the larger relative contributions from basaltic inclusions. Additional support for an ordinary chondrite (possibly type-LL) is provided by the $\mathrm{Ni} / \mathrm{Cr}$ ratio determined by linear regression for the glass spherules of reworked fallout deposit at 317.6 mblf $(2.37 \pm 0.08$; Fig. 9) and the whole rock nonfractionated, chondritic CI-normalized PGE patterns of the reworked fallout deposit at 318.9 mblf and melt rock fragments (Fig. 7).

\section{Implications for the Formation of El'gygytgyn's Microtektite-Like Spherules}

Simple mass-balance considerations suggest that the spherules did not form due to fractional condensation from a vapor cloud: given the relatively high abundances of components in the spherules with low volatilization temperatures, such as $\mathrm{Na}$ and $\mathrm{K}$, and the constraints for the possible projectile types, it seems most plausible that the El'gygytgyn spherules formed as the result of the accretion of melt droplets of target and ordinary chondritic impactor (compare Wittmann et al. 2012). Subsequently, Ni-rich spinel formed on the 


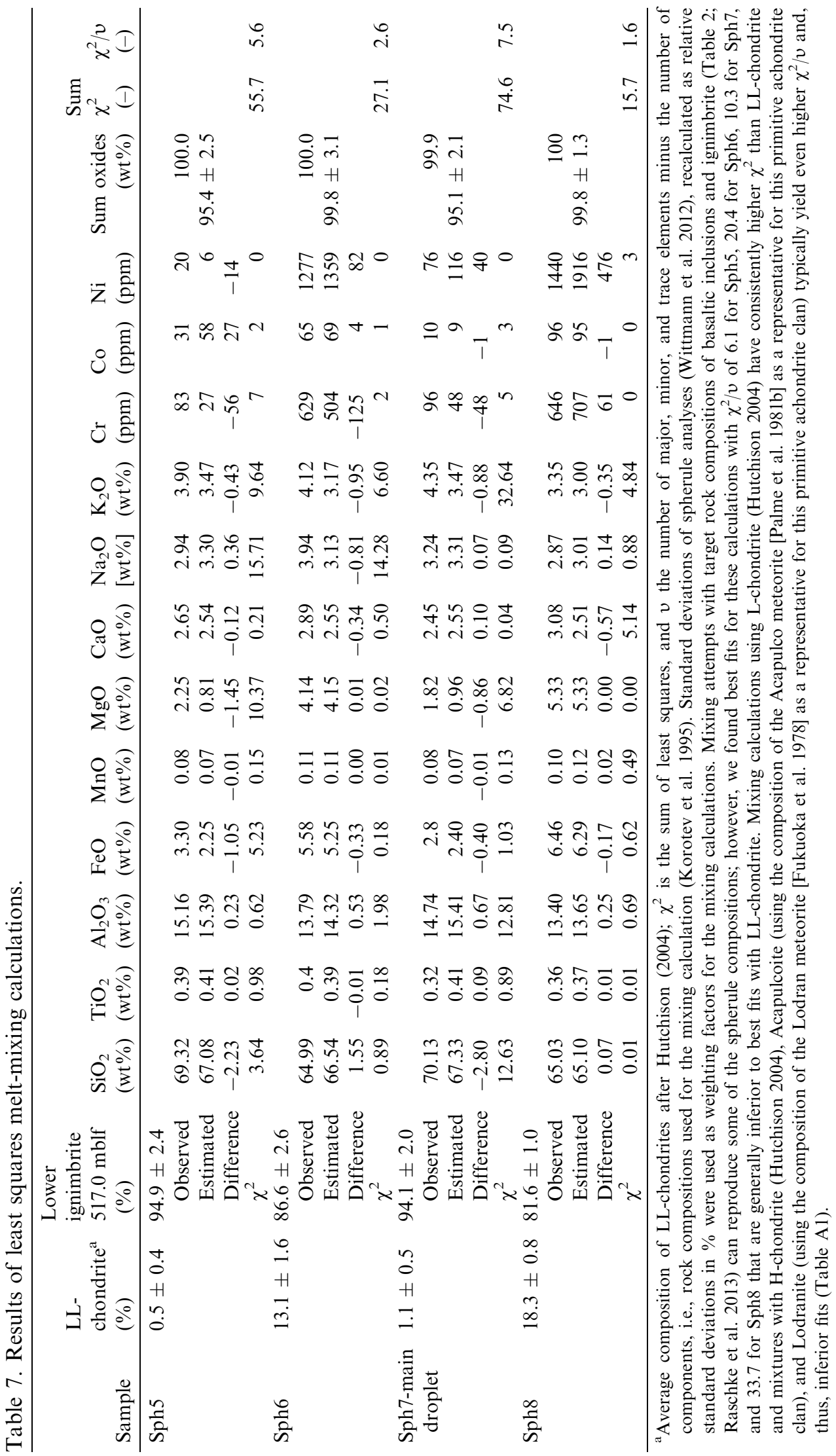


surface of melt droplets (Fig. 3) during their residence in the ejecta plume/fireball, sometimes prior to droplet accretion. In contrast, condensation from a vaporized achondrite projectile, such as the ureilite suggested in previous studies, would require the preferential incorporation of $\mathrm{Ni}$ and $\mathrm{Co}$ into the spherules, with close to $100 \%$ of the average concentration of these elements in ureilites (Warren et al. 2006) (Fig. 5c), while only approximately $10 \%$ of the $\mathrm{Cr}$ from an ureilite projectile would have contributed to the spherule composition. This mass-balance consideration seems implausible.

Melt-mixing calculations (Table 7) show that spherule compositions in the ICPD-drill cores can be produced from mixing ignimbrite target rock with LL-chondrite impactor. In contrast, spherules collected $\mathrm{SE}$ of the crater rim probably record the presence of an additional, surficial mafic target lithology (Stone et al. 2009; Wittmann et al. 2012). Wittmann et al. (2012) consider the ignimbrite sample 517.0 mblf as representative of surficial target lithologies that are grossly similar to the upper $250-450 \mathrm{~m}$ of "ignimbrites" and "tuffs and rhyolitic lava" that constituted the uppermost pre-impact target rock sequence in the SW, W, NW, N, and NE regions of the crater (Gurov and Gurova 1991). Thus, the El'gygytgyn spherules appear to record lateral target rock variations to a depth of $<0.5 \mathrm{~km}$. Following scaling relationships of Schmidt and Housen (1987) and constraints from numerical modeling (Collins et al. 2008), a projectile diameter of approximately $1.5 \mathrm{~km}$ can be assumed for the El'gygytgyn impact. These constraints can approximate the depth of target lithologies $\left(\mathrm{d}_{\mathrm{T}}\right)$ that contribute to microtektite-like spherules such as those from El'gygytgyn, to the diameter of a typical asteroidal projectile for the respective crater linked to these spherules $\left(D_{\mathrm{P}}\right)$ :

$$
\mathrm{d}_{\mathrm{T}}<D_{\mathrm{P}} / 3
$$

Although very tentative, this scaling relationship could be tested and refined by analyzing microtektitelike, glassy spherules from other terrestrial impact craters such as Bosumtwi (Koeberl et al. 2007) and Chicxulub (Sigurdsson et al. 1991).

\section{Ordinary Chondritic Impactors}

Chondrites are believed to dominate the main fraction of the extraterrestrial material reaching Earth, not only as meteorites (approximately $85 \%$ of the meteorites falling on Earth; Meteoritical Bulletin Database 2012), but possibly also as the impact craterforming projectiles of structures larger than $2 \mathrm{~km}$ (e.g., McDonald et al. 2001; Tagle and Claeys 2005), although the projectile composition down to the specific type of meteorite has been determined for only a small fraction of the confirmed impact structures (approximately 10 of 183 recognized on Earth today, i.e., close to $6 \%$ of the current impact crater population; Koeberl 2007; Tagle and Hecht 2006; Goderis et al. 2012).

The fall statistics of meteorites are dominated by ordinary chondrites: $38 \%$ L-type, 34.1\% H-type, and $7.9 \%$ LL-type chondrites (Burbine et al. 2002). Impact structures that resulted from the collisions of ordinary chondritic bodies with Earth include Carancas (0.014 km Ø, type H4-5), New Quebec (3.4 km Ø, type L?), Brent (3.8 km Ø, type L or LL), Wanapitei $(7.5 \mathrm{~km}$ $\varnothing$, type $\mathrm{L}$ or LL), Bosumtwi (10.5 km $\varnothing$, type $\mathrm{H}, \mathrm{L}$, or LL), Lappajärvi (23 km $\varnothing$, type $\mathrm{H}$ ), East Clearwater (26 km Ø, type LL or H?), Morokweng (70 km Ø, type LL), and Popigai (100 km Ø, type L) (Koeberl 2007; Kenkmann et al. 2009; Goderis et al. [2012] and references therein). These classifications are generally based on siderophile element abundances or ratios as well as $\mathrm{Os}$ and $\mathrm{Cr}$ isotope systematics. However, at Morokweng, a drill core within the impact melt rocks revealed a large $(25 \mathrm{~cm})$, unaltered, LL6-chondrite fragment as well as several smaller fragments, while at Carancas, multiple H4-5 chondrite fragments were recovered (Maier et al. 2006; Kenkmann et al. 2009; Weisberg et al. 2009).

Additionally, several Neoarchean-Paleoproterozoic spherule layers from South Africa and Western Australia are interpreted to originate from the impact of ordinary chondrites, on the basis of independent $\mathrm{Cr}$ isotope and PGE abundance evidence (e.g., Simonson et al. 2009). Only the Chicxulub impact structure concurrent with the Cretaceous-Paleogene boundary has convincingly been linked to a carbonaceous chondritic projectile (type CM2; Kyte 1998; Shukolyukov and Lugmair 1998; Trinquier et al. 2006). In addition, the 3.5-3.2 Ga old Barberton spherule layers in South Africa have been linked to carbonaceous chondrites (possibly type CV; Kyte et al. 2003).

Class C asteroids appear to be similar to carbonaceous chondritic meteorites (e.g., Zolensky 2005). Ordinary chondrites have recently been convincingly linked to S-type asteroids, the most abundant asteroids in the inner asteroid belt (e.g., Binzel et al. 2004; Abe et al. 2006; Nakamura et al. 2011). The Hayabusa mission returned samples from $S$ (IV)-type asteroid 25143 Itokawa that have been identified as ordinary chondritic (LL4-LL6) (e.g., Nakamura et al. 2011; Yurimoto et al. 2011). These data contradict the assertion of the domination of asteroid populations by C-class asteroids $(75 \%$ of the asteroids visible from Earth; Bell et al. 1989; Gaffey 
et al. 1993), while S-type asteroids only form the second largest group. Nevertheless, the current interpretations of the asteroidal spectra suggest that $\mathrm{OC}$ asteroids (S- and Q-type) dominate near-Earth objects (e.g., Pieters and McFadden 1994; Binzel et al. 2004).

Cosmic-ray exposure ages of LL-type ordinary chondrites record a major peak at approximately $15 \mathrm{Ma}$, consistent with a collisional breakup event, and minor clusters at approximately $10 \mathrm{Ma}, 28 \mathrm{Ma}$, and 40-50 Ma (Marti and Graf 1992). However, the systematics of ${ }^{40} \mathrm{Ar}-{ }^{39} \mathrm{Ar}$ retention ages show that only minor heating occurred during the roughly $15 \mathrm{Ma}$ collision of the LL-chondrite parent body. The youngest ${ }^{40} \mathrm{Ar}-{ }^{39} \mathrm{Ar}$ degassing episode recorded in an LL chondrite meteorite so far occurred approximately 400 Ma ago (e.g., Bogard 2011; Swindle et al. 2011).

\section{CONCLUSIONS}

This study tests the hypothesis for an ureilite impactor at the El'gygytgyn impact structure and concludes that an ordinary chondritic projectile is more likely.

1. Least squares mixing calculations using the small suite of samples analyzed in this study indicate that the (upper) polymict impact breccias in the El'gygytgyn 1C drill core are dominated by a rhyolitic ignimbrite composition, with only a minor addition of a basaltic (mafic) component (up to $13.5 \mathrm{wt} \%)$. The bulk rock composition of El'gygytgyn-ICDP 1C drill core samples and melt rock fragments recovered from the western rim of the impact crater appear to be derived from the upper $0.6 \mathrm{~km}$ of the target rock sequence. This is similar to the observations made for the impact melt particles in the suevite unit of this drill core (Wittmann et al. 2012). As the sampled mafic inclusions are not exposed at the surface, pronounced $\mathrm{Cr}$ and smaller $\mathrm{Ni}$ enrichments of characterized impactites led previous studies to suggest the presence of a primitive achondrite (ureilite) meteoritic contribution (Va'lter et al. 1982; Gurov and Koeberl 2004; Gurov et al. 2005).

2. The occurrence of a meteoritic component is confirmed based on: (1) the significantly enriched abundances and nonterrestrial ratios of the moderately siderophile elements measured for recovered impact glass spherules and spherule fragments (Wittmann et al. 2012); (2) a slight Ir enrichment with flat, nonfractionated CI-normalized logarithmic PGE patterns for the reworked fallout deposit and several impact rock fragments; (3) Os isotope ratios that are inconsistent with the target rock composition (including mafic, basaltic inclusion 391.6); and (4) the reported nonterrestrial $\mathrm{Cr}$ isotopic composition of an impact glass sample (Foriel et al. 2013). Provided elemental fractionation (e.g., during volatilization and/or oxidation) and a strongly heterogeneous impactor are precluded, the moderately siderophile element contents and their ratios in the characterized impact glass spherules and spherule fragments are not characteristic of ureilites. After exclusion of most types of differentiated achondrites (HED, angrites, and aubrites) and iron meteorites based on the $\mathrm{Ni} / \mathrm{Cr}, \mathrm{Ni} / \mathrm{Co}$, and $\mathrm{Cr} / \mathrm{Co}$ ratios and their generally fractionated CI-normalized PGE patterns, and carbonaceous chondrites based on the $\mathrm{Cr}$ isotope ratios measured for an impact glass (Foriel et al. 2013), ordinary chondrites remain as the most likely types of projectiles, followed by several types of primitive achondrites (Table 6).

3. The compositions of the characterized impact spherules and spherule fragments can be modeled as mixtures between rhyolitic ignimbrite target lithologies and 0.50 to $18 \mathrm{wt} \%$ of ordinary chondrite, with LL-type chondrites yielding the best fit (Table 7). Mixing models involving primitive achondritic and (ultra)mafic target contributions cannot produce the relative abundances of $\mathrm{Cr}$, Co, and $\mathrm{Ni}$ of the spherules in acceptable approximation.

The whole rock meteoritic enrichment is highest at the bottom of the reworked spherule-bearing fallout deposit, in impact melt rock fragments, and minor in a polymict impact breccia. Although the exact relationship with the presence of compositionally diverse impact glass spherules is not yet fully understood, the base of the reworked fallout deposit records the finest fraction of ejecta, suggesting that reworking and dilution were less effective there during redeposition. The absence of any PGEenriched target lithologies is essential for the detection and the identification of the very dilute projectile component at El'gygytgyn (approximately $0.05 \mathrm{wt} \%$ of nominal ordinary chondrite, possibly type-LL). This amount is comparable to the range of extraterrestrial components observed at many impact structures and ejecta materials (e.g., Tagle et al. 2004; Tagle and Claeys 2005; Goderis et al. 2007, 2012; Koeberl 2007). Similar to the low abundance of shock features and impact melt (Wittmann et al. 2012), the projectile component is too diluted for detection in the suevite unit.

4. The microtektite-like spherules from El'gygytgyn indicate formation as aggregates of melt droplets sourced from the upper target rock sequences and an ordinary chondritic impactor. Mass-balance 
considerations discredit formation due to condensation from an impactor vapor cloud. Tentatively, a scaling relationship is deduced between the depth of target lithologies that contributed to the microtektite-like spherules at El'gygytgyn and the assumed projectile diameter for that impact.

Acknowledgments - S. G. is a postdoctoral fellow of the Research Foundation-Flanders (FWO). P. C. and F. V. acknowledge the support of Research Foundation Flanders (grants G.A078.11 and G.0021.11). We gratefully acknowledge Tim Martin (Greensboro Day School) for the donation of impact melt rock samples TM8-17; Kentaro Tanaka for sample grinding at the VUB; David Kring for support at the LPI, Houston; Ulli Raschke (MfN Berlin) for sample processing and sharing his manuscripts for this proceedings volume; Julien Foriel for sharing his manuscript for this proceedings volume; Roald Tagle for the use of his meteorite siderophile element database; the El'gygytgyn Scientific Party and its sponsors (ICDP, Austrian Federal Ministry of Science and Research, Federal Ministry of Education and Research, Germany, German Science Foundation, Russian Academy of Sciences, U.S. National Science Foundation); Leonie Adolph for her to work on El'gygtgyn impact spherules; Michael Roden (Dept. of Geology, University of Georgia) for allowing to use the microscopy lab at UGA. We thank Fred Moynier, Christian Koeberl, and an anonymous reviewer for their thoughtful comments that helped to improve the manuscript significantly.

\section{Editorial Handling - Dr. Christian Koeberl}

\section{REFERENCES}

Abe M., Tagaki Y., Kitazato K., Abe S., Hiroi T., Vilas F., Clark B. E., Abell P. A., Lederer S. M., Jarvis K. S., Nimura T., and Fujiwara A. 2006. Near-infrared spectral results of asteroid Itokawa from the Hayabusa spacecraft. Science 312:1334-1338.

Adolph L. and Deutsch A. 2009. Glass spherules related to the El'gygtgyn impact crater (Siberia) (abstract \#1116). 41st Lunar and Planetary Science Conference. CD-ROM.

Adolph L. and Deutsch A. 2010. Trace element analysis of impact glass spherules of the El'gygytgyn crater, Siberia (abstract \#2421). 42nd Lunar and Planetary Science Conference. CD-ROM.

Alvarez L. W., Alvarez W., Asaro F., and Michel H. V. 1980. Extraterrestrial cause for the Cretaceous-Tertiary extinction. Science 208:1095-1108.

Anderson R. L. 1987. Practical statistics for analytical chemists. New York: Van Nostrand Reinhold. 352 p.

Bell J. F., Davis D. R., Hartmann W. K., and Gaffey M. J. 1989. Asteroids: The big picture. In Asteroids II, edited by
Binzel R. P., Gehrels T., and Matthews M. S. Tucson, Arizona: The University of Arizona Press. pp. 921-945.

Belyi V. F. 1998. Impactogenesis and volcanism of the El'gygytgyn depression. Petrologiya 6:86-99.

Binzel R. P., Rivikin A. S., Stuart S. S., Harris A. W., and Bus S. J. 2004. Observed spectral properties of near-Earth objects: Results for population distribution, source regions, and space weathering processes. Icarus 170:259-294.

Bogard D. D. 2011. K-Ar ages of meteorites: Clues to parentbody thermal histories. Chemie der Erde 71:207-226.

Buchwald V. F. 1975. Handbook of iron meteorites. Berkeley: University of California Press. 1418 p.

Burbine T. H., McCoy T. J., Meibom A., Gladman B., and Keil K. 2002. Meteoritic parent bodies: Their number and identification. In Asteroids III, edited by Bottke W. F., Jr., Cellino A., Paolicchi P., and Binzel R. P. Tucson, Arizona: The University of Arizona Press. pp. 653-667.

Claeys P., Kiessling W., and Alvarez W. 2002. Distribution of Chicxulub ejecta at the Cretaceous-Tertiary boundary. In Catastrophic events and mass extinctions: Impacts and beyond, edited by Koeberl C. and MacLeod K. G. Boulder, Colorado: Geological Society of America. pp. 55-68.

Collins G. S., Kenkmann T., Osinski G. R., and Wünnemann K. 2008. Mid-sized complex crater formation in mixed crystalline-sedimentary targets: Insight from modeling and observation. Meteoritics \& Planetary Science 43:19551977.

Dabizha A. I. and Feldman V. I. 1982. Geophysical characteristics of some astroblemes of the USSR. Meteoritika 40:91-101.

Doerffel K. 1990. Statistik in der analytischen chemie. Leipzig: VEB Deutscher Verlag für Grundstoffindustrie $\mathrm{GmbH}$. $256 \mathrm{p}$.

Earth Impact Database. 2012. Earth Impact Database: http:// www.passc.net/EarthImpactDatabase/index.html. Accessed December 15, 2012.

Evans N. J., Gregoire D. C., Grieve R. A. F., Goodfellow W. D., and Veizer J. 1993. Use of platinum-group elements for impactor identification: Terrestrial impact craters and Cretaceous-Tertiary boundary. Geochimica et Cosmochimica Acta 57:3737-3748.

Feldman V. I., Granovsky L. B., Kapustina I. G., Karoteeva N. N., Sazonova L. V., and Dabija A. I. 1981. Meteorite crater El'gygytgyn. In Impactites, edited by Marakhushev A. A. Moscow: Moscow State University Press. pp. 70-92.

Foriel J., Moynier F., Schulz T., and Koeberl C. 2013. Chromium isotope anomaly in an El'gygytgyn crater impactite: Evidence for a ureilite projectile. Meteoritics \& Planetary Science 48, doi: 10.1111/maps.12116.

Fukuoka T., Ma M.-S., Wakita H., and Schmitt R. A. 1978. Lodran: The residue of limited partial melting of matter like a hybrid between $\mathrm{H}$ and $\mathrm{E}$ chondrites (abstract). 9th Lunar and Planetary Science Conference. p. 356.

Gaffey M. J., Burbine T. H., and Binzel R. P. 1993. Asteroid spectroscopy: Progress and perspectives. Meteoritics \& Planetary Science 28:161-187.

Gebhardt A. C., Niessen F., and Kopsch C. 2006. Central ring structure identified in one of the world's best-preserved impact craters. Geology 34:145-148.

Gelinas A., Kring D. A., Zurcher L., Urrutia-Fucugauchi J., Morton O., and Walker R. J. 2004. Osmium isotope constraints on the proportion of bolide component in Chicxulub impact melt rocks. Meteoritics \& Planetary Science 39:1003-1008. 
GeoRem. 2012. http://georem.mpch-mainz.gwdg.de. Accessed December 15, 2012.

Glushkova O. and Smirnov V. 2005. General geology and geography. In Ber. Polarforsch. Meeresforsch., edited by Melles M., Minyuk P., Bringham-Grette J., and Juschus O. Leipzig: Institute for Geophysics and Geology. pp. 14 18.

Goderis S., Tagle R., Schmitt R. T., Erzinger J., and Claeys P. 2007. Platinum group elements provide no indication of a meteoritic component in ICDP cores from the Bosumtwi crater, Ghana. Meteoritics \& Planetary Science 42:731-741.

Goderis S., Kalleson E., Tagle R., Dypvik H., Schmitt R. T., Erzinger J., and Claeys P. 2009. A non-magmatic iron projectile for the Gardnos impact event. Chemical Geology 258:145-156.

Goderis S., Hertogen J., Vanhaecke F., and Claeys P. 2010. Siderophile elements from the Eyreville drill cores of the Chesapeake Bay impact structure do not constrain the nature of the projectile. In Large meteorite impacts and planetary evolution $I V$, edited by Gibson R. L. and Reimold W. U. GSA Special Paper 465. Boulder, Colorado: Geological Society of America. pp. 395-409.

Goderis S., Paquay F., and Claeys P. 2012. Projectile identification in terrestrial impact structures and ejecta material. In Impact cratering: Processes and products, edited by Osinski G. and Pierazzo E. New York: WileyBlackwell. pp. 223-239.

Govindaraju K. 1994. Compilation of working values and description for 383 geostandards. Geostandards Newsletter 18:1-154.

Grieve R. A. F., Dence M. R., and Robertson P. B. 1977. Cratering processes: A interpreted from the occurrence of impact melts. In Impact and explosion cratering, edited by Roddy D. J., Pepi R. O., and Merrill R. B. New York: Pergamon Press. pp. 791-814.

Gurov E. P. and Gurova E. P. 1991. Geological structure and rock composition of impact structures. Kiev: Naukova Dumka Press. 160 p.

Gurov E. P. and Koeberl C. 2004. Shocked rocks and impact glasses from the El'gygytgyn impact structure. Russia. Meteoritics \& Planetary Science 39:1495-1508.

Gurov E. P., Valter A. A., Gurova E. P., and Serebrennikov A. I. 1978. Explosion meteorite crater Elgygytgyn, Chukotka. Doklady Akademiia Nauk SSSR 240:1407-1410.

Gurov E. P., Valter A. A., Gurova E. P., and Kotlovskaya F. I. 1979a. Elgygytgyn impact crater, Chukotka: Shock metamorphsim of volcanic rocks. Proceedings, 10th Lunar and Planetary Science Conference. pp. 479-481.

Gurov E. P., Gurova E. P., and Rakitskaia R. B. 1979b. Stishovite and coesite in shock-metamorphosed rocks of the El'gygytgyn crater in Chukotka. Doklady Akademiia Nauk SSSR 248:213-216.

Gurov E., Koeberl C., Reimold W. U., Brandstätter F., and Amare K. 2005. Shock metamorphism of siliceous volcanic rocks of the El'gygytgyn impact crater (Chukotka, Russia). In Large meteorite impacts III, edited by Kenkmann T., Hörz F., and Deutsch A. Boulder, Colorado: Geological Society of America. pp. 391-412.

Gurov E. P., Koeberl C., and Yamnichenko A. 2007. El'gygytgyn impact crater, Russia: Structure, tectonics, and morphology. Meteoritics \& Planetary Science 42:307-319.

Hall G. E. M. and Pelchat J. C. 1994. Analysis of geochemical materials for gold, platinum and palladium at low ppb levels by fire assay-ICP mass spectrometry. Chemical Geology 115:61-72.

Hassler D. R., Peucker-Ehrenbrink B., and Ravizza G. E. 2000. Rapid determination of Os isotopic composition by sparging $\mathrm{OsO}_{4}$ into a magnetic-sector ICP-MS. Chemical Geology 166:1-14.

Heiken G. H., McKay D. S., and Brown R. W. 1974. Lunar deposits of possible pyroclastic origin. Geochimica et Cosmochimica Acta 38:1703-1738.

Hutchison R. 2004. Meteorites. A petrologic, chemical and isotopic synthesis. Cambridge: Cambridge University Press. $506 \mathrm{p}$.

Jenniskens P., Shaddad M. H., Numan D., Elsir S., Kudoda A. M., Zolensky M. E., Le L., Robinson G. A., Friedrich J. M., Rumble D., Steele A., Chesley S. R., Fitzsimmons A., Duddy S., Hsieh H. H., Ramsay G., Brown P. G., Edwards W. N., Tagliaferri E., Boslough M. B., Spalding R. E., Dantowitz R., Kozubal M., Pravec P., Borovicka J., Charvat Z., Vaubaillon J., Kuiper J., Albers J., Bishop J. L., Mancinelli R. L., Sandford S. A., Milam S. N., Nuevo M., and Worden S. P. 2009. The impact and recovery of asteroid $2008 \mathrm{TC}_{3}$. Nature 458:485-488.

Kapustina I. G., Feldman V. I., and Kolesov G. M. 1985. Behaviour of some meteoritic material indicator elements in process of impact melt degassing. Proceedings, 16th Lunar and Planetary Science Conference. pp. 422-423.

Kenkmann T., Artemieva N. A., Wunnemann K., Poelchau M. H., Elbeshausen D., and del Prado H. N. 2009. The Carancas meteorite impact crater, Peru: Geologic surveying and modeling of crater formation and atmospheric passage. Meteoritics \& Planetary Science 44:985-1000.

Koeberl C. 2007. The geochemistry and cosmochemistry of impacts. In Meteorites, comets, and planets, edited by Holland H. D. and Turekian K. K. Treatise on Geochemistry, vol. 1. Elsevier. pp. 1.28.1-1.28.52, doi:10. 1016/B978-008043751-4/00228-5, online edition.

Koeberl C., Peucker-Ehrenbrink B., Reimold W. U., Shukolyukov A., and Lugmair G. W. 2002. Comparison of $\mathrm{Os}$ and $\mathrm{Cr}$ isotopic methods for the detection of meteoritic components in impactites: Examples from the Morokweng and Vredefort impact structures, South Africa. In Catastrophic events \& mass extinctions: Impacts and beyond, edited by Koeberl C. and MacLeod K. G. Boulder, Colorado: Geological Society of America. pp. 607-617.

Koeberl C., Brandstätter F., Glass B. P., Hecht L., Mader D., and Reimold W. U. 2007. Uppermost impact fallback layer in the Bosumtwi crater (Ghana): Mineralogy, geochemistry, and comparison with Ivory Coast tektites. Meteoritics \& Planetary Science 42:709-729.

Koeberl C., Pittarello L., Reimold U., Raschke U., BrighamGrette J., Melles M., and Minyuk P. 2012. El'gygytgyn impact crater, Chukotka, Arctic Russia: Impact cratering aspects of the 2009 ICDP drilling project. Meteoritics \& Planetary Science. 48, doi:10.1111/maps.12146.

Korotev R. L., Haskin L. A., and Jolliff B. L. 1995. A simulated geochemical rover mission to the Taurus-Littrow valley of the Moon. Journal of Geophysical Research 100:14,403-14,420.

Kyte F. T. 1998. A meteorite from the Cretaceous/Tertiary boundary. Nature 396:237-239.

Kyte F. T., Shukolyukov A., Lugmair G. W., Lowe D. R., and Byerly G. R. 2003. Early Archean spherule beds: 
Chromium isotopes confirm origin through multiple impacts of projectiles of carbonaceous chondrite type. Geology 31:283-286.

Layer P. W. 2000. Argon-40/argon-39 age of the El'gygytgyn impact event, Chukotka. Russia. Meteoritics \& Planetary Science 35:591-600.

Maier W. D., Andreoli M. A. G., McDonald I., Higgins M. D., Boyce A. J., Shukolyukov A., Lugmair G. W., Ashwal L. D., Graser P., Ripley E. M., and Hart R. J. 2006. Discovery of a $25-\mathrm{cm}$ asteroid clast in the giant Morokweng impact crater, South Africa. Nature 411:203206.

Marti K., and Graf T. 1992. Cosmic-ray exposure history of ordinary chondrites. Annual Review of Earth and Planetary Sciences 20:221-243.

McDonald I. 2002. Clearwater East impact structure: A reinterpretation of the projectile type using new platinumgroup element data. Meteoritics \& Planetary Science 37:459-464.

McDonald I., Andreoli M. A. G., Hart R. J., and Tredoux M. 2001. Platinum-group elements in the Morokweng impact structure, South Africa: Evidence for the impact of a large ordinary chondrite projectile at the Jurassic-Cretaceous boundary. Geochimica et Cosmochimica Acta 65:299-309.

McDonough W. F. and Sun S. S. 1995. The composition of the Earth. Chemical Geology 120:223-253.

Meisel T. and Moser J. 2004. Reference materials for geochemical PGE analysis: New analytical data for Ru, $\mathrm{Rh}, \mathrm{Pd}$, Os, Ir, Pt and Re by isotope dilution ICP-MS in 11 geological reference materials. Chemical Geology 208:319-338.

Meisel T., Walker R. J., Irving A. J., and Lorand J.-P. 2001. Osmium isotopic compositions of mantle xenoliths: A global perspective. Geochimica et Cosmochimica Acta 65:1311-1323.

Melles M., Minyuk P., Brigham-Grette J., and Juschus O., eds. 2005. The expedition El'gygytgyn Lake 2003 (Siberian Arctic). Ber. Polarforsch. Meeresforsch. Leipzig: Institute for Geophysics and Geology. 139 p.

Melles M., Brigham-Grette J., Minyuk P., Koeberl C., Andreev A., Cook T., Fedorov G., Gebhardt C., HaltiaHovi E., Kukkonen M., Nowaczyk N., Schwamborn G., Wennrich V., and Party T. E. G. S. 2011. The Lake El'gygytgyn Scientific Drilling Project-Conquering Arctic challenges through continental drilling. Scientific Drilling 11:15-40.

Melles M., Brigham-Grette J., Minyuk P. S., Nowaczyk N. R., Wennrich V., DeConto R. M., Anderson P. M., Andreev A. A., Coletti A., Cook T. L., Haltia-Hovi E., Kukkonen M., Lozhkin A. V., Rosén P., Tarasov P., Vogel H., and Wagner B. 2012. 2.8 million years of Arctic climate change from Lake El'gygytgyn, NE Russia. Science 337:315-320.

Meteoritical Bulletin Database. 2012. http://www.lpi.usra.edu/ meteor/. Accessed December 15, 2012.

Morgan J. W. and Wandless G. A. 1983. Strangways Crater, northern territory, Australia: Siderophile element enrichment and lithophile element fractionation. Journal of Geophysical Research 88:A819-A829.

Morgan J. W., Ganapathy R., and Anders E. 1975. Meteoritic material in four terrestrial meteorite craters. Proceedings, 6th Lunar Science Conference. pp. 1609-1623.

Morgan J. W., Janssens M.-J., Hertogen J., Gros J., and Takahashi H. 1979. Ries impact crater, southern
Germany: Search for meteoritic material. Geochimica et Cosmochimica Acta 43:803-815.

Nakamura T., Noguchi T., Tanaka M., Zolensky M. E., Kimura M., Tsuchiyama A., Nakato A., Ogami T., Ishida H., Uesugi M., Yada T., Shirai K., Fujimura A., Okazaki R., Sandford S. A., Ishibashi Y., Abe M., Okada T., Ueno M., Mukai T., Yoshikawa M., and Kawaguchi J. 2011. Itokawa dust particles: A direct link between S-type asteroids and ordinary chondrites. Science 333:1113-1116.

Nowaczyk N. R., Minyuk P., Melles M., Brigham-Grette J., Glushkova O., Nolan M., Lozhkin A. V., Stetsenko T. V., Andersen P. M., and Forman S. L. 2002. Magnetostratigraphic results from impact crater Lake El'gygytgyn, northeastern Siberia: A 300 kyr long highresolution terrestrial palaeoclimatic record from the Arctic. Geophysical Journal International 150:109-126.

Palme H. 1980. The meteoritic contamination of terrestrial and lunar impact melts and the problem of indigenous siderophiles in the lunar highland. Proceedings, 11th Lunar and Planetary Science Conference. pp. 481-506.

Palme H. 1982. Identification of projectiles of large terrestrial impact craters and some implications for the interpretation of Ir-rich Cretaceous/Tertiary boundary layers. In Geological implication of impacts of large asteroids and comets on Earth, edited by Silver L. T. and Schultz P. H. Boulder, Colorado: Geological Society of America. pp. 223-233.

Palme H., Janssens M.-J., Takahasi H., Anders E., and Hertogen J. 1978. Meteorite material at five large impact craters. Geochimica et Cosmochimica Acta 42:313-323.

Palme H., Grieve R. A. F., and Wolf R. 1981a. Identification of the projectile at the Brent crater and further consideration of projectile types at terrestrial craters. Geochimica et Cosmochimica Acta 45:2417-2424.

Palme H., Schultz L., Spettel B., Weber H. W., Wänke H., Michel-Levy M. C., and Lorin J. C. 1981b. The Acapulco meteorite: Chemistry, mineralogy and irradiation effects. Geochimica et Cosmochimica Acta 45:727-752.

Palme H. and O'Neill H. St. C. 2004. Cosmochemical estimates of mantle composition. In Mantle and core, Treatise on Geochemistry, vol. 2, edited by Holland H. D. and Turrekian K. K. Amsterdam: Elsevier. pp. 1-38.

Pernicka E., Horn P., and Pohl J. 1987. Chemical record of the projectile in the graded fall-back sedimentary unit from the Ries Crater, Germany. Earth and Planetary Science Letters 86:113-121.

Peucker-Ehrenbrink B. and Jahn B.-M. 2001. Rheniumosmium isotope systematics and platinum-group element concentrations: Loess and the upper continental crust. Geochemistry Geophysics Geosystems 2, doi:10.1029/ 2001 GC000172.

Pieters C. M. and McFadden L. A. 1994. Meteorite and asteroid reflectance spectroscopy: Clues to early solar system processes. Annual Review of Earth and Planetary Sciences 22:457-497.

Plessen H.-G. and Erzinger J. 1998. Determination of the platinum-group elements and gold in twenty rock reference material by inductively coupled plasma-mass spectrometry (ICPMS) after pre-concentration by nickel fire assay. Geostandards Newsletter 22:187-194.

Rankenburg K., Brandon A. D., and Humayan M. 2007. Osmium isotope systematics of ureilites. Geochimica et Cosmochimica Acta 71:2402-2413. 
Raschke U., Reimold W. U., and Schmitt R. T. 2013. Petrography and geochemistry of the impactites of the ICDP drill core D1c from Lake El'gygytgyn, NE Russia. Meteoritics \& Planetary Science 48, doi:10.1111/ maps. 12087.

Rollinson H. R. 1993. Using geochemical data: Evaluation, presentation, interpretation. Harlow, UK: Longman Publishing Group. 352 p.

Schmidt R. M. and Housen K. R. 1987. Some recent advances in the scaling of impact and explosion cratering. International Journal of Impact Engineering 5:543-560.

Schmidt G. and Pernicka E. 1994. The determination of platinum group elements (PGE) in target rocks and fall-back material of the Nördlinger Ries impact crater (Germany). Geochimica et Cosmochimica Acta 58:5083-5090.

Shukolyukov A. and Lugmair G. W. 1998. Isotopic evidence for the Cretaceous-Tertiary impactor and its type. Science 282:927-929.

Sigurdsson H., D'Hondt S., Arthur M. A., Bralower T. J., Zachos J. C., van Fossen M., and Channell J. E. T. 1991. Glass from the Cretaceous/Tertiary boundary in Haiti. Nature 349:482-487.

Simonson B. M., McDonald I., Shukolyukov A., Koeberl C., Reimold U. W., and Lugmair G. W. 2009. Geochemistry of 2.63-2.49 Ga impact spherule layers and implications for stratigraphic correlations and impact processes. Precambrian Research 175:51-76.

Smit J. and Hertogen J. 1980. An extraterrestrial event at the Cretaceous-Tertiary boundary. Nature 285:198-200.

Stone D. B., Layer P. W., and Raikevich M. I. 2009. Age and paleomagnetism of the Okhotsk-Chukotka Volcanic Belt (OCVB) near Lake El'gygytgyn, Chukotka, Russia. Stephan Mueller Special Publication Series 4:243-260.

Swindle T. D., Weirich J. R., Isachsen C. E., Wittmann A., and Kring D. A. 2011. ${ }^{40} \mathrm{Ar}-{ }^{39} \mathrm{Ar}$ dating of Larkman nunatak 06299: comparison to paired LAR 06298 and to other LL chondrites (abstract \#5497). 74th Annual Meteoritical Society Meeting. CD-ROM.

Tagle R. 2004. Platingruppenelemente in Meteoriten und Gesteinen irdischer Impaktkrater: Identifizierung der Einschlagskörper. Ph.D. thesis. Humboldt-Universität, Berlin, Germany.

Tagle R. and Berlin J. 2008. A database of chondrite analyses including platinum group elements, $\mathrm{Ni}, \mathrm{Co} ., \mathrm{Au}$, and $\mathrm{Cr}$ : Implications for the identification of chondritic projectiles. Meteoritics \& Planetary Science 43:541-559.

Tagle R. and Claeys P. 2005. An ordinary chondrite impactor for the Popigai crater, Siberia. Geochimica et Cosmochimica Acta 69:2877-2889.

Tagle R. and Hecht L. 2006. Geochemical identification of projectiles in impact rocks. Meteoritics \& Planetary Science 41:1721-1735.
Tagle R., Erzinger J., Hecht L., Schmitt R. T., Stoffler D., and Claeys P. 2004. Platinum group elements in impactites of the ICDP Chicxulub drill core Yaxcopoil-1: Are there traces of the projectile? Meteoritics \& Planetary Science 39:1009-1016.

Tagle R., Schmitt R. T., and Erzinger J. 2009. Identification of the projectile component in the impact structures Rochechouart France and Sääksjärvi, Finland: Implications for the impactor population for the Earth. Geochimica et Cosmochimica Acta 73:4891-4906.

Taylor S. R. and McLennan S. M. 1985. The continental crust: Its composition and evolution. Oxford: Blackwell Publication. p. 312.

Trinquier A., Birck J.-L., and Allègre C. J. 2006. The nature of the KT impactor. A ${ }^{54} \mathrm{Cr}$ reappraisal. Earth and Planetary Science Letters 241:780-788.

Va'lter A. A., Barchuk I. F., Bulkin V. S., Ogorodnik A. F., and Kotishevskaya E. Y. 1982. The El'gygytgyn meteorite: Probable composition. Soviet Astronomical Letters (Pisma Astr. Zh.) 8:115-120.

Warren P. H., Ulff-Møller F., Huber H., and Kallemeyn G. W. 2006. Siderophile geochemistry of ureilites: A record of early stages of planetesimal core formation. Geochimica et Cosmochimica Acta 70:2104-2126.

Wasson J. T. and Kallemeyn G. W. 1988. Composition of chondrites. Philosophical Transactions of the Royal Society of London A 325:535-544.

Wedepohl K. H. 1995. The composition of the continental crust. Geochimica et Cosmochimica Acta 59:1217-1232.

Weisberg M. K., Smith C., Benedix G., Folco L., Righter K., Zipfel J., Yamaguchi A., and Chennaoui Aoudjehane H. 2009. The Meteoritical Bulletin, No. 95. Meteoritics \& Planetary Science 44:1-33.

Wittmann A., Goderis S., Claeys P., Vanhaecke F., Deutsch A., and Adolph L. 2013. Petrology of impactites from the El'gygytgyn crater: Breccias in ICDP-drill hole 1C, glassy impact melt rocks and spherules. Meteoritics \& Planetary Science 48, doi:10.1111/maps.12019.

Wolf R., Woodrow A. B., and Grieve R. A. F. 1980. Meteoritic material at four Canadian impact craters. Geochimica et Cosmochimica Acta 44:1015-1022.

Yurimoto H., Abe K., Abe M., Ebihara M., Fujimura A., Hashiguchi M., Hashizume K., Ireland T. R., Itoh S., Katayama J., Kato C., Kawaguchi J., Kawasaki N., Kitajima F., Kobayashi S., Meike T., Mukai T., Nagao K., Nakamura T., Naraoka H., Noguchi T., Okazaki R., Park C., Sakamoto N., Seto Y., Takei M., Tsuchiyama A., Uesugi M., Wakaki S., Yada T., Yamamoto K., Yoshikawa M., and Zolensky M. E. 2011. Oxygen isotopic composition of asteroidal material returned from Itokawa by the Hayabusa mission. Science 333:1116-1119.

Zolensky M. E. 2005. Extraterrestrial water. Elements 1:39-44. 


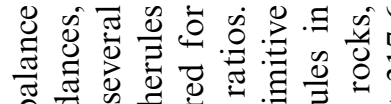

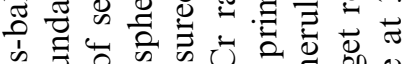

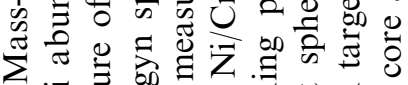

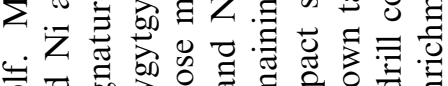

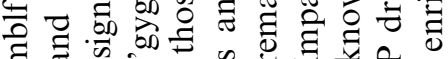

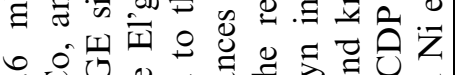

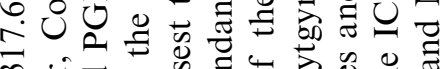

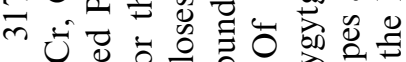

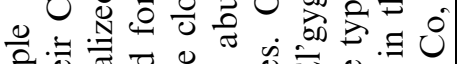

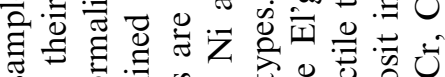
\%

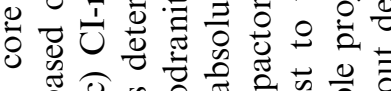

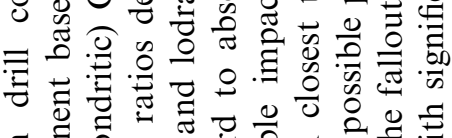
छ घ

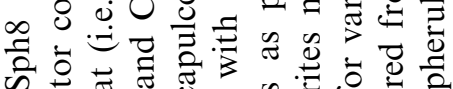

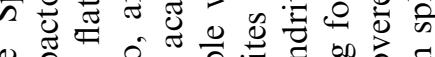

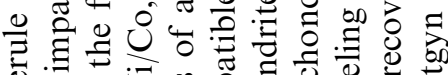

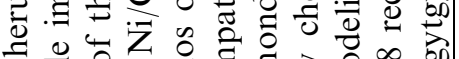

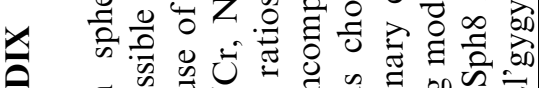

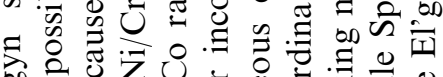
on

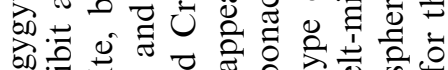

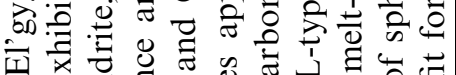

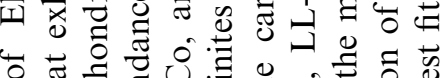

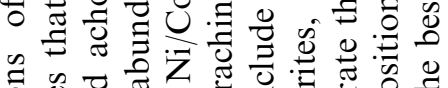

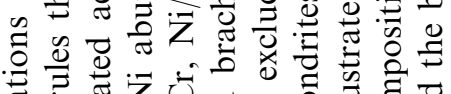

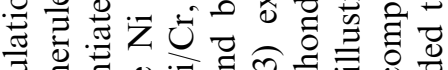

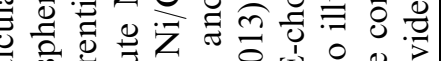
च की कo $0: \begin{aligned} & 0 \\ & 0\end{aligned}$

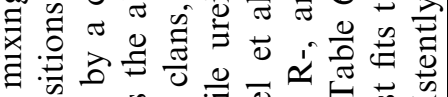

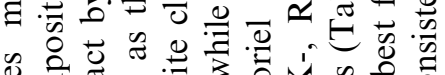

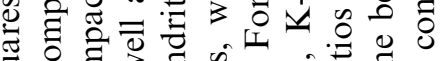

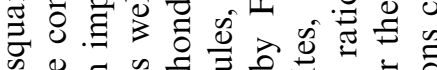

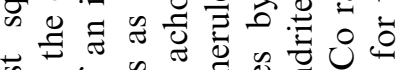

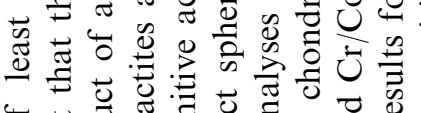

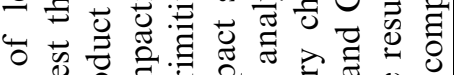

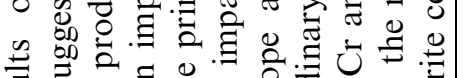

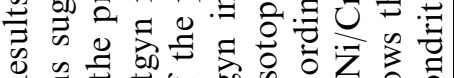

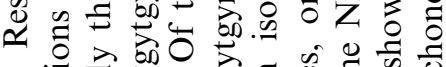

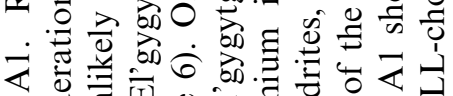

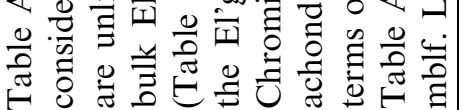

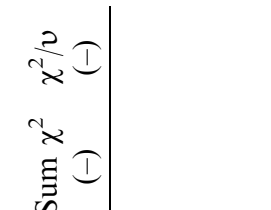

$\begin{array}{ll}\stackrel{+}{m} & \stackrel{0}{-} \\ \stackrel{\sim}{m} & \ddot{n}\end{array}$

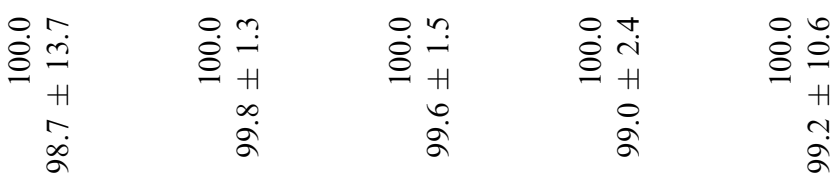

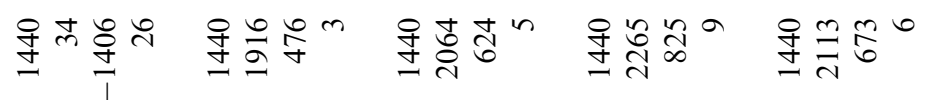
ஃレ

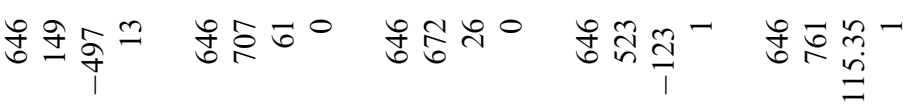

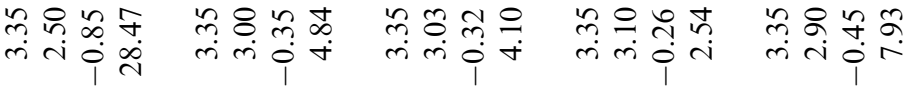

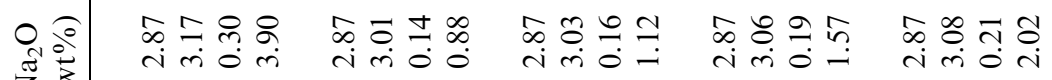
Z 运

O

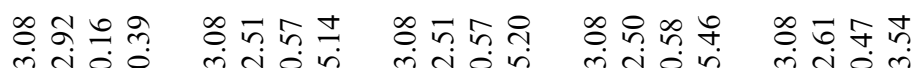

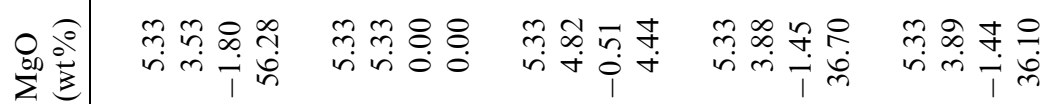

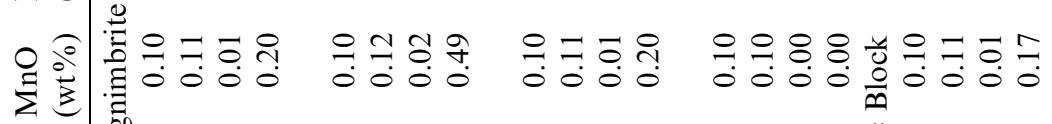

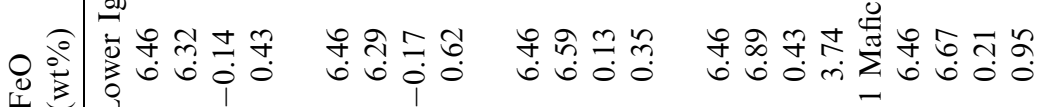
0.0-

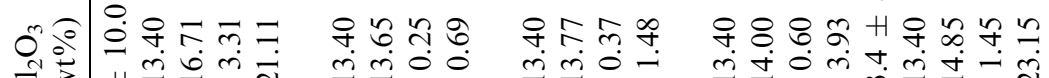

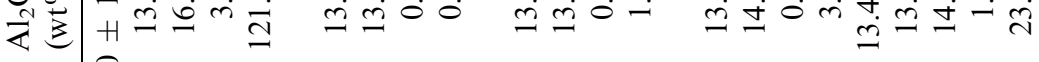

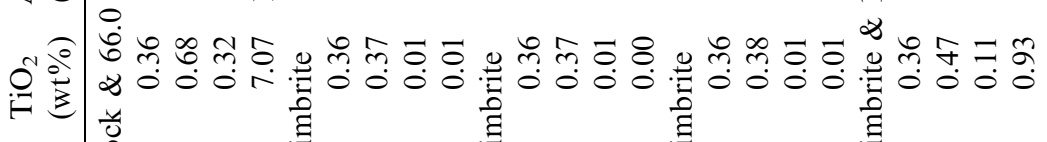
त $\frac{\partial}{\circ}$ 응 ๆ 约

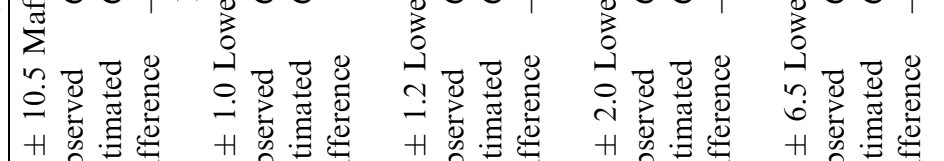

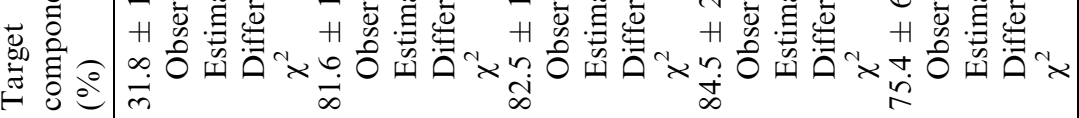

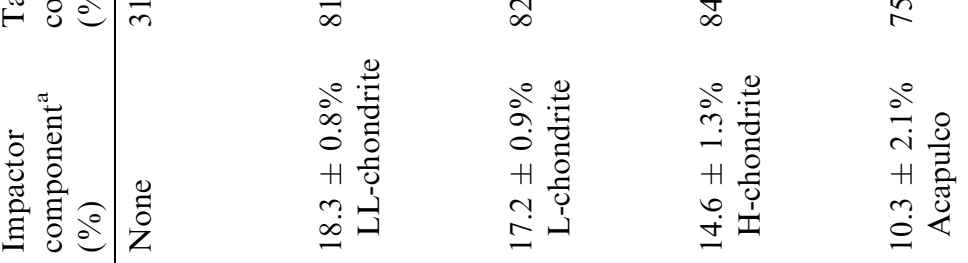




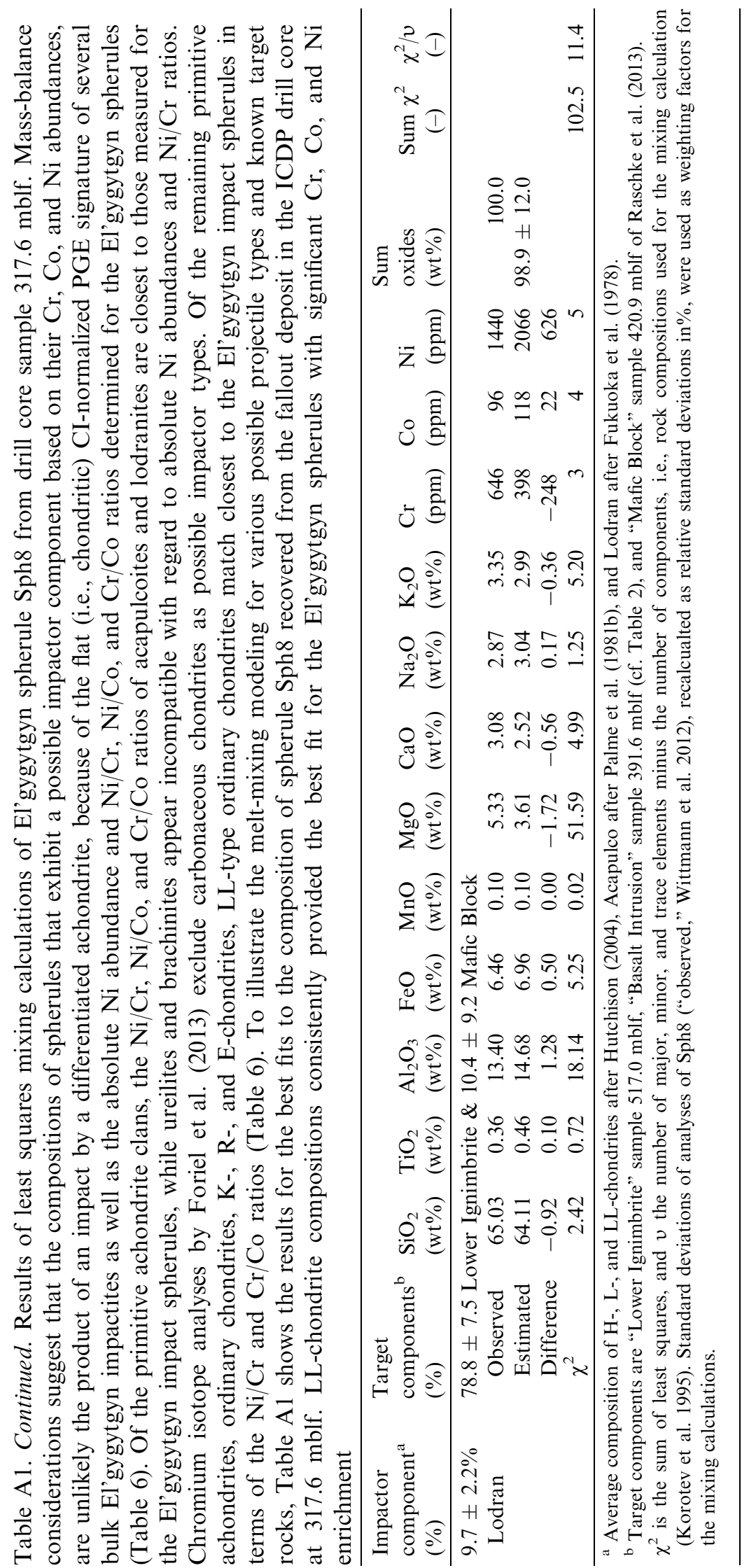

